\title{
Pitting Corrosion Behavior and Surface Microstructure of Copper Strips When Rolled with Oil-in-Water Emulsions
}

\author{
Xudong Yan ${ }^{1, *}$ and Jianlin Sun ${ }^{2}$ \\ 1 School of Materials Science and Engineering, Beihang University, No. 37 Xueyuan Road, Beijing 100191, China \\ 2 School of Materials Science and Engineering, University of Science and Technology Beijing, \\ Beijing 100083, China; sjl@ustb.edu.cn \\ * Correspondence: yanxudong@buaa.edu.cn; Tel.: +86-178-0102-4054
}

check for updates

Citation: Yan, X.; Sun, J. Pitting Corrosion Behavior and Surface Microstructure of Copper Strips When Rolled with Oil-in-Water Emulsions. Materials 2021, 14, 7911. https://doi.org/10.3390/ma14247911

Academic Editor: Bożena Łosiewicz

Received: 19 November 2021 Accepted: 13 December 2021 Published: 20 December 2021

Publisher's Note: MDPI stays neutral with regard to jurisdictional claims in published maps and institutional affiliations.

Copyright: (c) 2021 by the authors. Licensee MDPI, Basel, Switzerland. This article is an open access article distributed under the terms and conditions of the Creative Commons Attribution (CC BY) license (https:// creativecommons.org/licenses/by/ $4.0 /)$.

\begin{abstract}
Copper strips experience severe corrosion when rolled with an oil-in-water $(\mathrm{O} / \mathrm{W})$ emulsions lubricant. The effects of rolling reduction on the pitting corrosion behavior and surface microstructure of $\mathrm{Cu}$ strips were studied in detail using electrochemical measurements and electron back scattered diffraction (EBSD) analysis. It was found that the corrosion current densities of the rolled $\mathrm{Cu}$ strips increased with accumulated reduction, which also lowered the pitting potentials and weakened their corrosion resistances. Therefore, the corrosive tendency of $\mathrm{Cu}$ strips under different rolling reductions ( $(\varepsilon)$ followed the order of $\varepsilon_{0} \%<\varepsilon_{20.7 \%}<\varepsilon_{50.6 \%}<\varepsilon_{77.3 \%}$. The Cu surface easily reacted with chlorine, sulfur, and carbon components from $\mathrm{O} / \mathrm{W}$ emulsions to generate pitting corrosion. Under the interactive effect of pitting corrosion and stress corrosion, pits expanded along the rolling direction. The aggregation of anions in surface defects, such as dislocations, metastable pits, and microcracks, further accelerated the pitting corrosion of the surface.
\end{abstract}

Keywords: copper strip; rolling reduction; surface microstructure; emulsion; pitting corrosion

\section{Introduction}

Copper $(\mathrm{Cu})$ and its alloy strips have been widely applied in the fields of mechanical, aviation, and electronic information due to their excellent electrical conductivity, thermal conductivity, reliability, and workability [1-6]. Cold rolling is one of the key techniques of the $\mathrm{Cu}$ strip manufacturing processes. Oil-in-water $(\mathrm{O} / \mathrm{W})$ emulsions are commonly served as the technical lubricants to optimize the dimensional accuracy and to improve the surface quality of the $\mathrm{Cu}$ strips during cold rolling [7]. Although $\mathrm{Cu}$ has good corrosion resistance in an ordinary environment (dry atmosphere), it still suffers severe corrosion when exposed to high temperature, high humidity, cold, shock, vibration, and high shear stress environments during employment [8]. In particular, when $\mathrm{Cu}$ products are exposed to solutions such as $\mathrm{O} / \mathrm{W}$ emulsions with complicated components for a long time, their surface qualities and usage performance will be weakened. This issue has attracted considerable attention from researchers $[9,10]$.

In our previous studies, it was found that copper corrosion possessed an incubation period. $\mathrm{Cu}$ could react with $\mathrm{O}$ atoms in emulsions and gradually transformed to $\mathrm{Cu}^{+}$and $\mathrm{Cu}^{2+}$. Then, components that contained hydroxide and carboxylate anions would adsorb on the $\mathrm{Cu}$ surface to generate copper compounds such as $\mathrm{Cu}_{2} \mathrm{O}, \mathrm{CuO}, \mathrm{Cu}(\mathrm{OH})_{2}, \mathrm{CuCO}_{3}$, and $\mathrm{Cu}_{2}(\mathrm{OH})_{2} \mathrm{CuCO}_{3}$ [11]. Furthermore, $\mathrm{pH}$ values, water hardness, additives, and other auxiliary reagents influenced the corrosion properties of the $\mathrm{Cu}$ surface. Soluble ions in hard tap water changed the electrochemical conductivity, resulting in the disruption of the passive layers, which accelerated the pitting corrosion, and the weak alkaline solutions contributed to the inhibition of pitting corrosion [12]. However, the above studies only concerned the influences of properties of $\mathrm{O} / \mathrm{W}$ emulsion itself on $\mathrm{Cu}$ corrosions. Cold rolling is a complicated process. With the rolling reduction accumulated, cold working deformations of $\mathrm{Cu}$ samples might develop in large evolutions on their grain boundaries 
and grain size [13]. These deformations not only affected the microstructure of $\mathrm{Cu}$, but also had a significant impact on its corrosion behavior.

Related scholars have studied the relationship between the deformation degree and corrosion behavior of copper, but the conclusions are not consistent. Robin [14] investigated the corrosion resistance of $\mathrm{Cu}$ grains in $\mathrm{H}_{2} \mathrm{SO}_{4}$ solutions during the cold-swaged and cold-wiredrawn machining process, and found the corrosion resistance decreased with the deformation degree. Lapeire [15] studied the influence of grain size on the electrochemical behavior of pure copper in $0.1 \mathrm{M} \mathrm{HCl}$ and pointed out that for a smaller grain size, a lower corrosion potential and higher corrosion current density were observed. On the contrary, Deng and Nikfahm $[16,17]$ stated that the ultrafine-grained copper enhanced its anti-corrosion behavior. During the cold rolling process, although $\mathrm{Cu}$ grain has not experienced recrystallization, the atomic arrangement and surface defect distribution on the microstructure of $\mathrm{Cu}$ will be changed by rolling reduction, in which the corrosion properties were still unclear. Furthermore, with the rolling reduction accumulated, the distribution of residual stress on the $\mathrm{Cu}$ surface may also have an impact on its corrosive order. Therefore, a deep understanding of these aspects, including electrochemical processes, surface morphologies, microstructure evolutions, and mechanical properties on the corrosion behavior of the cold-rolled $\mathrm{Cu}$ strips need to be studied.

In this paper, the electrochemical performances of the rolled $\mathrm{Cu}$ strips as electrodes in $\mathrm{O} / \mathrm{W}$ emulsions were investigated using potendiodynamic polarization and electrochemical impedance spectroscopy (EIS) measurements. The microstructure of $\mathrm{Cu}$ strips under different rolling reductions was observed by electron back scattered diffraction (EBSD) analysis. Their surface mechanical properties were also figured out and the pitting corrosion mechanism of $\mathrm{Cu}$ surface was discussed based on surface and cross-section characterizations.

\section{Materials and Methods}

\subsection{Materials and $\mathrm{O} / \mathrm{W}$ Emulsions Preparation}

The component of experimental $\mathrm{Cu}$ sample is shown in Table 1, which was obtained from the same raw strip as our previous study [18]. The strip was at hard state without any heat treatment and was cut with a size of $10 \mathrm{~mm} \times 10 \mathrm{~mm} \times 1.98 \mathrm{~mm}$. Ethanol and de-ionized water were used for cleaning the $\mathrm{Cu}$ sample before the tests.

Table 1. Component of the raw $\mathrm{Cu}$ strip in this investigation.

\begin{tabular}{ccccccc}
\hline Component & $\mathrm{Cu}$ & $\mathrm{Pb}$ & $\mathrm{S}$ & $\mathrm{Cd}$ & $\mathrm{P}$ & $\mathrm{Fe}$ \\
\hline Wt. $\%$ & 99.9900 & 0.0003 & 0.0016 & 0.0002 & 0.0013 & 0.0009 \\
\hline
\end{tabular}

The O/W emulsion was composed of $95 \mathrm{wt} . \%$ tap water and $5 \mathrm{wt} . \%$ emulsified oils. Mineral oil D130 and rapeseed oil are the main components of emulsified oils. Their composition and physiochemical properties are shown in Table 2. The other reagents included surfactants (sorbitan oleate); emulsifiers (oleic acid and triethanolamine), and anti-wear additives (Dibutyl Phosphite). Sorbitan oleate $\left(\mathrm{C}_{24} \mathrm{H}_{44} \mathrm{O}_{6}, \geq 98 \%\right.$, AR), oleic acid $\left(\mathrm{C}_{8} \mathrm{H}_{17} \mathrm{CH}=\mathrm{CH}\left(\mathrm{CH}_{2}\right)_{7} \mathrm{COOH}, \geq 99 \%\right.$, AR $)$ and triethanolamine $\left(\mathrm{N}\left(\mathrm{CH}_{2} \mathrm{CH}_{2} \mathrm{OH}\right)_{3}, \geq 99 \%\right.$, AR) were purchased from Sinopharm Chemical Reagent Beijing Co., Ltd., Beijing, China. Dibutyl phosphite $\left(\left(\mathrm{C}_{4} \mathrm{H}_{90}\right)_{2} \mathrm{POH}, \geq 99 \%\right.$, AR) was provided by Qianyang Technology Hangzhou Co., Ltd., Hangzhou, China. All chemicals were newly produced and used as received without further purification. 
Table 2. Details on composition and physiochemical properties of mineral oil D130 and rapeseed oil.

\begin{tabular}{|c|c|c|}
\hline Properties & Mineral Oil D130 & Rapeseed Oil \\
\hline Main compositions & $\begin{array}{c}\text { Direct alkane, } \\
\text { Branched alkane, } \\
\text { Cycloalkanes }\end{array}$ & $\begin{array}{l}\text { Erucic acid, } \\
\text { Arachidic acid, } \\
\text { Linoleic acid, } \\
\text { linolenic acid }\end{array}$ \\
\hline Aromatics content (wt. $\%)$ & 0.5 & - \\
\hline Sulfur content (wt.\%) & $<0.1$ & $<0.1$ \\
\hline Phosphorous content (wt.\%) & $<0.1$ & $<0.1$ \\
\hline Viscosity for $40^{\circ} \mathrm{C}\left(\mathrm{mm}^{2} / \mathrm{s}\right)$ & 6.12 & $13.5 \sim 14.0$ \\
\hline Flash point $\left({ }^{\circ} \mathrm{C}\right)$ & $>140$ & $>110$ \\
\hline Suppliers & $\begin{array}{c}\text { Sinopec Group Shanghai Co., } \\
\text { Ltd., Shanghai, China }\end{array}$ & $\begin{array}{l}\text { Red Oil Chengdu Ltd., } \\
\text { Chengdu, China }\end{array}$ \\
\hline Year of production & 2017 & 2019 \\
\hline
\end{tabular}

The preparation process of $\mathrm{O} / \mathrm{W}$ emulsions is presented in Figure 1. Firstly, $1.4 \mathrm{~g}$ rapeseed oil, $2.1 \mathrm{~g}$ surfactants, $0.6 \mathrm{~g}$ emulsifiers, and $0.65 \mathrm{~g}$ anti-wear additives were gradually dissolved into $15.25 \mathrm{~g}$ base oil and mixed at $25^{\circ} \mathrm{C}$ for $10 \mathrm{~min}$ to obtain the equably emulsified oils. Subsequently, the mixture was heated at $60^{\circ} \mathrm{C}$ with a reactor and stirred for $20 \mathrm{~min}$. It was then diluted with tap water to $5 \mathrm{wt} . \%$ at the same temperature. After stirring and cooling, and the $\mathrm{O} / \mathrm{W}$ emulsion was completely prepared. The ionic concentration compositions of $\mathrm{O} / \mathrm{W}$ emulsions were measured using ion chromatography, and the result is shown in Table 3.

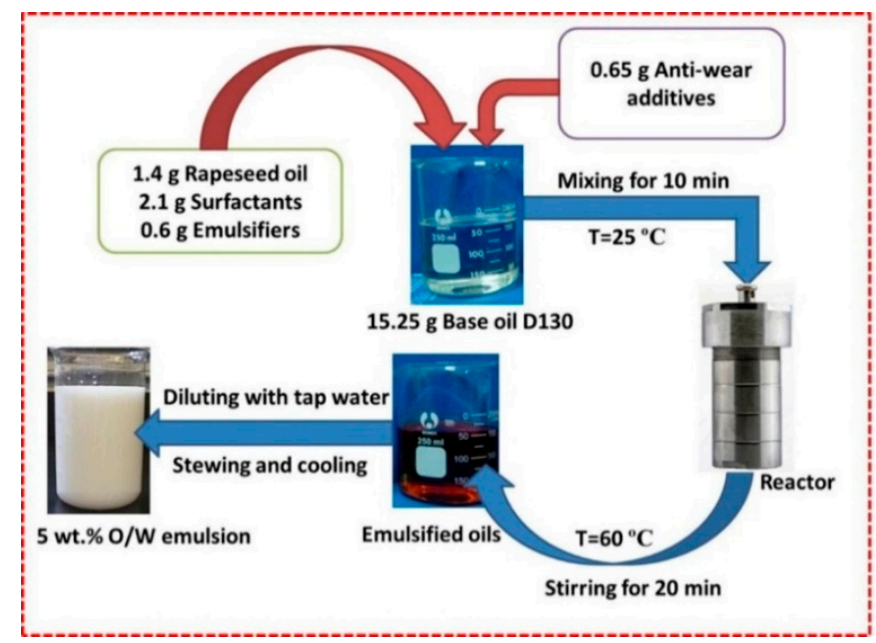

Figure 1. Preparation process of $\mathrm{O} / \mathrm{W}$ emulsion.

Table 3. Ionic concentration of the prepared $\mathrm{O} / \mathrm{W}$ emulsion.

\begin{tabular}{ccccccccc}
\hline Ionic Types & $\mathrm{Cl}^{-}$ & $\mathrm{NO}_{3}^{-}$ & $\mathrm{SO}_{4}^{2-}$ & $\mathrm{PO}_{4}^{3-}$ & $\mathrm{K}^{+}$ & $\mathrm{Ca}^{2+}$ & $\mathrm{Na}^{+}$ & $\mathrm{Mg}^{2+}$ \\
\hline $\begin{array}{c}\text { Concentrations } \\
(\mathbf{p p m})\end{array}$ & 15.62 & 21.78 & 71.52 & 6.35 & - & 67.26 & 13.94 & 6.39 \\
\hline
\end{tabular}

\subsection{Cold Rolling Tests}

Cold rolling test of the $\mathrm{Cu}$ strip was conducted using a $\Phi 130 \times 220 \mathrm{~mm}$ two-high mill with a velocity of $13 \mathrm{r} / \mathrm{min}$ and a rolling power of $5.5 \mathrm{~kW}$ at $25^{\circ} \mathrm{C}$. O/W emulsions that served as lubricants were added at the deformation zone to obtain thinner strip with higher surface quality. The reduction ratio of each pass was constantly restricted at $20 \%$. The rolled thickness of each pass is shown in Table 4. Due to the influence of the spring-back error, the actual strip thickness of each pass was larger. In this work, $\mathrm{Cu}$ strips under a different accumulated reduction of $0 \%$ (raw strip), 20.7\% (small reduction strip), 58.6\% 
(moderate reduction strip), and 77.3\% (large reduction strip) were recollected as samples for subsequent electrochemical measurements and EBSD analysis.

Table 4. Actual rolled thickness of each pass.

\begin{tabular}{ccccccc}
\hline Rolling Pass & 0 & 1 & 2 & 3 & 4 & 5 \\
\hline Thickness $(\mathbf{m m})$ & 1.98 & 1.85 & 1.57 & 1.16 & 0.82 & 0.45 \\
\hline
\end{tabular}

\subsection{Electrochemical Measurement}

Electrochemical measurements were performed by a multichannel potentiodynamic system (VersaSTAT, AMETEK, Berwyn, PA, USA) equipped with a conventional threeelectrode cell. A $4 \mathrm{~cm}^{2}$ platinum sheet was utilized as the auxiliary electrode, a saturated calomel electrode (SCE) functioned as the reference electrode, and the cold-rolled $\mathrm{Cu}$ strips were used as the working electrodes. The working electrodes were connected with $\mathrm{Cu}$ wire and embedded into epoxy resin, leaving a $1 \mathrm{~cm}^{2}$ cross-sectional area exposure for electrochemical experiments. All of the $\mathrm{Cu}$ electrodes were abraded with 800 to 2000 grit silicon carbide papers gradually and then polished with $0.5 \mathrm{SiO}_{2}$ anti-scuffing paste to obtain a minor-like appearance before the electrochemical measurements.

The open circuit potential (OCP) was first measured to achieve a steady state. Subsequently, EIS tests were performed at a frequency ranging from $10^{5}$ to $10^{-2} \mathrm{~Hz}$, using an AC signal with an amplitude of $10 \mathrm{mV}$. The EIS data were analyzed carefully by Zsimpwin software (3.30d, Echem, Ann Arbor, MI, USA). Finally, potentiodynamic polarization measurements were carried out and the results were recorded from a potential ranging from $-1.5 \mathrm{~V}$ to $1.5 \mathrm{~V}$ at a scan rate of $1 \mathrm{mV} / \mathrm{s}$. Before the tests, the electrodes were immersed in the same $\mathrm{O} / \mathrm{W}$ emulsion with a $\mathrm{pH}$ value of 7.8 , which served as the corrosive medium. All of the electrochemical experiments performed referred to the OCP in a temperaturecontrolled water bath at $25 \pm 2{ }^{\circ} \mathrm{C}$ for $2 \mathrm{~h}$. All of the measurements were performed thrice to ensure a satisfactory reproducibility.

\subsection{Surface Observations}

The surface morphologies of the corroded $\mathrm{Cu}$ electrodes were observed with laser scanning confocal microscopy (LSCM, LEXT OLS4100, OLYMPUS, Tokyo, Japan) and field emission scanning electron microscopy (FE-SEM, Nova Nano-SEM450, FEI, Hillsboro, OR, USA). X-ray photoelectron spectroscopy (XPS, ESCALAB 250 Xi, Thermo Fisher Scientific, Bedford, MA, USA) was carried out to analyze the components of the corrosion products on the surface. The cross-section microstructure of the pits was analyzed by the combined use of FIB/SEM (Helios Nanolab 600i, FEI, Hillsboro, OR, USA). The dislocation configurations on the microstructure of the rolled $\mathrm{Cu}$ strips were observed by transmission electron microscopy (TEM, FEI Tecnai G2 F20, FEI, Hillsboro, OR, USA).

\subsection{EBSD Characterizations}

For the preparation of the EBSD samples, these four $\mathrm{Cu}$ samples were electropolished using a voltage of $3.0 \mathrm{~V}$ for $40 \mathrm{~s}$ in a phosphoric acid electrolyte, which consisted of $175 \mathrm{~mL}$ phosphoric acid and $825 \mathrm{~mL}$ deionized water. The microstructure of the $\mathrm{Cu}$ sample was examined in a JSM-7900F FE-SEM equipped with an EDAX OIM EBSD system and the operation voltage was set as $20 \mathrm{keV}$. The characterizations were conducted by scanning a large area of $500 \times 500 \mu \mathrm{m}^{2}$ with a step size of $0.8 \mu \mathrm{m}$ to ensure that the results presented the real microstructure. All of the EBSD samples were placed with one accord, exposing the rolling directions (RD) and the transverse direction (TD) for microstructural observations. OIM Analysis software (6.2, EDAX, Philadelphia, PA, USA) was used for the EBSD data processing. 


\subsection{Mechanical Properties Tests}

The microhardness of the near-pit sites on the $\mathrm{Cu}$ strips was implemented through an EM-1500L Vickers indentation instrument. As shown in Figure 2, under the effect of indentation load, the material began to crack at the top corner and the crack length could be measured when it was unloaded. The hardness $(H)$ was calculated as follows,

$$
H=\frac{P}{S}=\frac{P \times 2 \sin \frac{\theta}{2}}{d^{2}}=1.854 \times \frac{P}{d^{2}}
$$

where $P$ is the preload; $d$ is the diagonal length of indentation; and $\theta$ is $136^{\circ}$, representing the angle between the diamond indenter and sample plane.

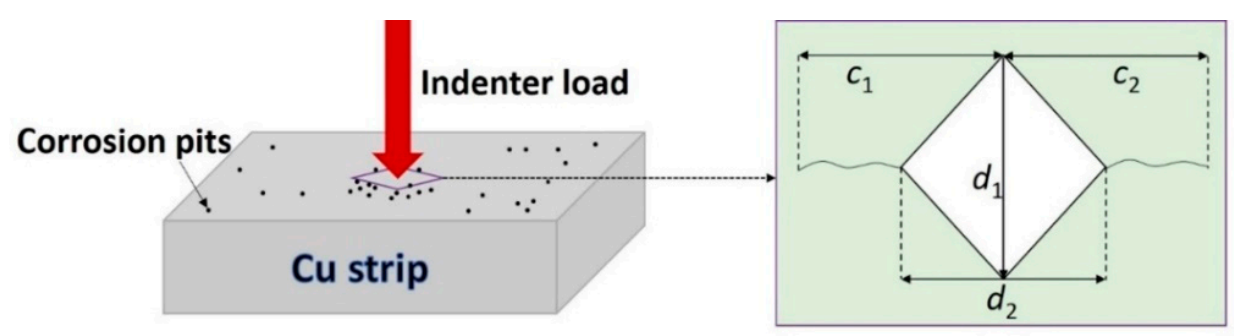

Figure 2. Principle of the Vickers indentation methods.

Subsequently, referring to Lawn's theory, two mechanical properties, namely the fracture toughness $\left(K_{\mathrm{IC}}\right)$ and residual stress $\left(\sigma_{\gamma}\right)$, in $\mathrm{Cu}$ strips were deduced from the following data. Assuming the influence of $\sigma_{\gamma}$ was uniform, $K_{\text {IC }}$ could be calculated using Formula (2) [19],

$$
K_{I C}=\chi \frac{p}{C^{2 / 3}}+\frac{2}{\sqrt{\pi}} \sigma_{\gamma} C^{1 / 2}-\frac{2}{\sqrt{\pi}} \sigma_{\gamma} \frac{t}{C^{1 / 2}}
$$

$t$ and $\chi$ are the parameters that were further obtained by Formulas (3) and (4),

$$
\begin{gathered}
t=\frac{d}{2 \tan \theta} \\
\chi=\delta\left(\frac{E}{H}\right)^{1 / 2}
\end{gathered}
$$

where $\delta$ is the indenter geometry factor, $E$ is the elastic modulus of $\mathrm{Cu}$ strips, and $C$ is the crack length.

\section{Results and Discussion}

\subsection{Electrochemical Corrosion Properties}

Table 5 shows the detail electrochemical parameters, including the corrosion potential $\left(E_{\text {corr }}\right)$, corrosion current density $\left(i_{\text {corr }}\right)$, anodic Tafel slope $\left(\beta_{\mathrm{a}}\right)$, and cathodic Tafel slope $(\beta c)$, which are deduced through the Tafel linear extrapolation method (as shown in Figure 3a). It is found that the initial anodic current density linearly increases with the potentials. When the $\mathrm{Cu}$ electrode passes the Tafel polarization region, a "potential plateau" phenomenon is observed at this stage and the $\log i_{\text {corr }}$ value hardly moves with the increase of $E_{\text {corr }}$. This "potential plateau" commonly referred to as a passivation region, which is due to the formation of intermediate species such as $\mathrm{CuO}_{2}$ and $\mathrm{CuCl}_{2}^{-}$on the electrode surface via the chemical reaction between $\mathrm{Cu}$ electrodes and solutions $[20,21]$. When the potential reaches a certain value, $\log i_{\text {corr }}$ increases again and the corrosion of the $\mathrm{Cu}$ electrode is accelerated. This generally causes pitting corrosion on the electrode surface and the potential value in this case is defined as the pitting potential $\left(E_{\mathrm{p}}\right)$ [22]. 
Table 5. Potentiodynamic polarization parameters of $\mathrm{Cu}$ electrodes under different rolling reduction.

\begin{tabular}{cccccc}
\hline Reduction & $E_{\text {corr }}(\mathbf{m V})$ & $\boldsymbol{i}_{\text {corr }}\left(\mathbf{A} / \mathbf{c m}^{2}\right)$ & $\beta_{\mathbf{a}}(\mathrm{V} / \mathbf{d e c})$ & $\beta_{\mathbf{c}}(\mathrm{V} / \mathbf{d e c})$ & $E_{\mathbf{p}}(\mathrm{V})$ \\
\hline $0 \%$ & -134 & $1.23 \times 10^{-6}$ & 3.09 & -1.92 & 0.58 \\
$20.7 \%$ & -425 & $9.55 \times 10^{-6}$ & 2.98 & -2.01 & 0.45 \\
$58.6 \%$ & -505 & $1.76 \times 10^{-5}$ & 2.75 & -2.09 & 0.41 \\
$77.3 \%$ & -527 & $2.56 \times 10^{-5}$ & 2.99 & -1.98 & 0.11 \\
\hline
\end{tabular}
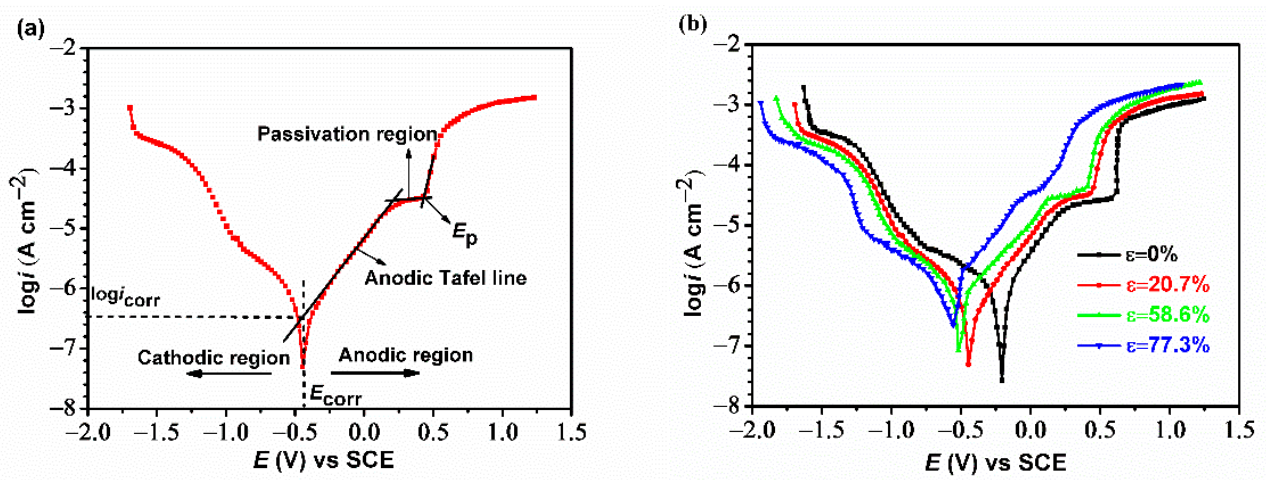

Figure 3. Potentiodynamic polarization results of $\mathrm{Cu}$ electrodes in the $\mathrm{O} / \mathrm{W}$ emulsions: (a) Tafel extrapolation method of the anodic polarization curve and $(\mathbf{b})$ polarization curves under different rolling reductions.

Potentiodynamic polarization curves of $\mathrm{Cu}$ electrodes under different cold rolling reduction in the $\mathrm{O} / \mathrm{W}$ emulsions are shown in Figure $3 \mathrm{~b}$. It is observed that there are not significant changes for both of the anodic slope $\left(\beta_{\mathrm{a}}\right)$ and cathodic slope $\left(\beta_{\mathrm{c}}\right)$ reflecting the similar polarization behavior of these four curves. The $i_{\text {corr }}$ of the raw $\mathrm{Cu}$ electrode in the $\mathrm{O} / \mathrm{W}$ emulsion is $1.23 \times 10^{-6} \mathrm{~A} / \mathrm{cm}^{2}$. With the accumulation of the rolling reduction, the values of $\log i_{\text {corr }}$ gradually increase and $E_{\text {corr }}$ shifts towards being more negative in the anodic region. This indicates $\mathrm{Cu}$ suffers more serious corrosion as the rolling process extends. In particular, when the $\mathrm{Cu}$ strip experienced a $77.3 \%$ reduction, the $E_{\mathrm{p}}$ of the $\mathrm{Cu}$ electrode abruptly decreases and the passivation region subsequently disappears, which means that pitting corrosion occurs easily on the $\mathrm{Cu}$ surface with a larger reduction.

The Nyquist plots of the $\mathrm{Cu}$ electrodes in the $\mathrm{O} / \mathrm{W}$ emulsions are displayed in Figure 4a. The curves show depressed semicircles in the high-frequency region, followed by straight lines in the low-frequency region. Generally, the semicircles are related to charge transfer resistance and double-layer capacitance. The low-frequency impedances are ascribed to Warburg impedances, which can be explained by the mass diffusion of the corrosion reactants and products towards or away from the $\mathrm{Cu}$ surface [23-25]. At the high-frequency impedance region, the electrode of the raw $\mathrm{Cu}$ strip exhibits the largest impedance and its diameter reduces with the increase of cold rolling reduction. Affected by $\mathrm{O} / \mathrm{W}$ emulsion, $\mathrm{Cu}$ bulks are adsorbed by some soluble ions, then the film resistance and film capacitance are existed on its surface. Therefore, the $R(Q(R(Q(R W))))$ equivalent electrochemical circuit model is most suitable to fit this measurement, wherein $R_{\mathrm{s}}$ is the solution resistance in $\mathrm{O} / \mathrm{W}$ emulsions, and $R_{\mathrm{f}}$ and $R_{\mathrm{ct}}$ represent the protective film resistance and charge transfer resistance, respectively. The polarization resistance $R_{\mathrm{po}}\left(R_{\mathrm{po}}=R_{\mathrm{f}}+R_{\mathrm{ct}}\right)$ is dominantly controlled by the charge transfer process, as the value of $R_{\mathrm{f}}$ is relatively smaller. $W$ stands for Warburg impedance. $Q_{\mathrm{f}}$ and $Q_{\mathrm{dl}}$ are the constant phase elements (CPE), representing the film capacitance and double-layer capacitance, respectively [24]. The parameters of the EIS results of different reduced Cu electrodes in the $\mathrm{O} / \mathrm{W}$ emulsions are shown in Table 6. 

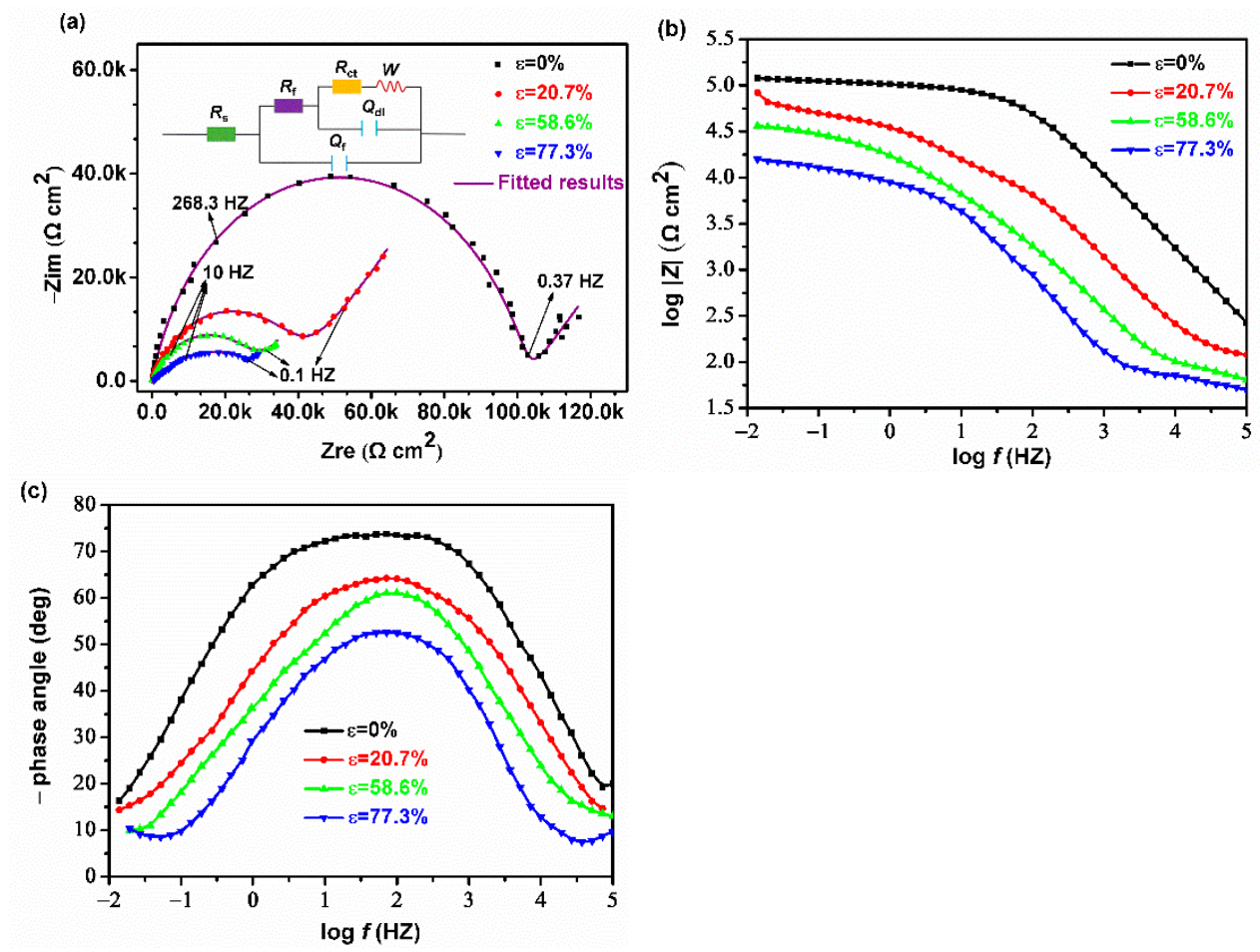

Figure 4. EIS results of $\mathrm{Cu}$ electrodes under different rolling reductions in the $\mathrm{O} / \mathrm{W}$ emulsions: (a) Nyquist plot, (b) Bode absolute plots, and (c) Bode phase plots.

Table 6. Parameters of the EIS results of different reduced $\mathrm{Cu}$ electrodes in $\mathrm{O} / \mathrm{W}$ emulsions.

\begin{tabular}{|c|c|c|c|c|c|c|c|}
\hline Reduction & $\begin{array}{c}R_{\mathrm{ct}} \\
\left(\mathrm{k} \Omega \mathrm{cm}^{2}\right)\end{array}$ & $\begin{array}{c}R_{\mathrm{f}} \\
\left(\mathrm{k} \Omega \mathrm{cm}^{2}\right)\end{array}$ & $\begin{array}{c}R_{\mathrm{po}} \\
\left(\mathrm{k} \Omega \mathrm{cm}^{2}\right)\end{array}$ & $\begin{array}{c}R_{\mathrm{S}} \\
\left(\mathrm{k} \Omega \mathrm{cm}^{2}\right)\end{array}$ & $\begin{array}{c}Q_{\mathrm{f}} \\
\left(\mu \mathrm{F} \mathrm{cm}^{-2}\right)\end{array}$ & $\begin{array}{c}Q_{\mathrm{dl}} \\
\left(\mu \mathrm{F} \mathrm{cm}^{-2}\right)\end{array}$ & $\begin{array}{c}W \\
\left(\times 10^{-2} \Omega \mathrm{cm}^{2} \mathrm{~S}^{1 / 2}\right)\end{array}$ \\
\hline $0 \%$ & 107.82 & 1.12 & 108.94 & 2.81 & 12.68 & 25.64 & 18.62 \\
\hline $20.7 \%$ & 44.08 & 0.42 & 44.50 & 2.82 & 18.86 & 38.40 & 15.64 \\
\hline $58.6 \%$ & 28.31 & 0.38 & 28.69 & 2.81 & 24.42 & 50.42 & 31.08 \\
\hline $77.3 \%$ & 20.27 & 0.32 & 20.59 & 2.82 & 28.82 & 340.64 & 40.12 \\
\hline
\end{tabular}

Figure $4 b, c$ presents the Bode absolute plots and Bode phase plots of different rolled $\mathrm{Cu}$ electrodes in the $\mathrm{O} / \mathrm{W}$ emulsions. The impedance values of the $\mathrm{Cu}$ samples were found to significantly decrease with cold rolling reduction over the whole frequency range. Meanwhile, their phase angles at low frequencies decreased with the accumulated reduction. Generally, larger values of log $|Z|$ always represent a superior protection performance [21], while low phase angle values at low frequencies usually indicate corrosion. From these figures, it can be inferred that the rolling procedure could weaken the corrosion resistance of copper.

\subsection{Surface Analysis}

The $\mathrm{Cu}$ electrodes after $2 \mathrm{~h}$ of electrochemical measurements were dried subsequently and further observed with a laser scanning confocal microscope. The 3D topographies and height profiles of the $\mathrm{Cu}$ samples before and after the electrochemical tests are displayed in Figure 5. As all of the $\mathrm{Cu}$ electrodes were fresh polished before the tests, as shown in Figure 5a,c,e,g, their topographies seemed smooth. With the reduction accumulated, a small quantity of shallow rolling trace appeared on the $\mathrm{Cu}$ surface. The topographies became much rougher after the electrochemical tests. From the 3D topography in Figure 5b, it is found that some dispersive pits appeared on the raw strip surface. These pits became denser with the increase of the rolling reduction (as shown in Figure $5 d, f, h$ ). In particular, while $\mathrm{Cu}$ experienced the largest deformation of $77.3 \%$ reduction, the small pits aggregated and propagated to form larger corrosion pits. The height profile includes the information 
of mean height of profile irregularities $\left(R_{\mathrm{a}}\right)$, maximum height of profile peak $\left(R_{\mathrm{p}}\right)$, and maximum depth of profile valley $\left(R_{\mathrm{v}}\right)$ of the $\mathrm{Cu}$ samples. As shown in the figures, the $R_{\mathrm{a}}$ values of uncorroded electrodes were around $0.05 \mu \mathrm{m}$. However, with the corrosion occurring, the height profile of these electrodes became fluctuant. It can be seen that each graph exhibits larger absolute values of $R_{\mathrm{v}}$ than $R_{\mathrm{p}}$, indicating that pitting corrosion largely exists on the $\mathrm{Cu}$ surface. As the rolling reduction increases, the height profile curves of the rolled $\mathrm{Cu}$ strips exhibited fluctuations. The topographies became rougher with severer pitting corrosion occurring on the surface.
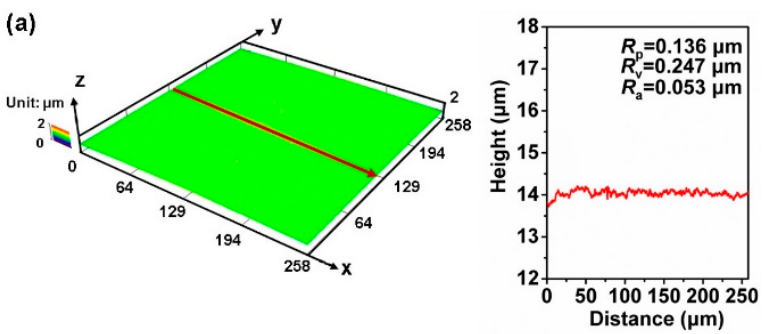

(c)

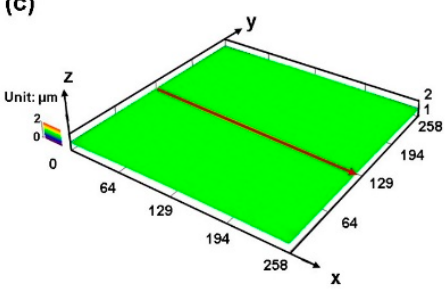

(e)
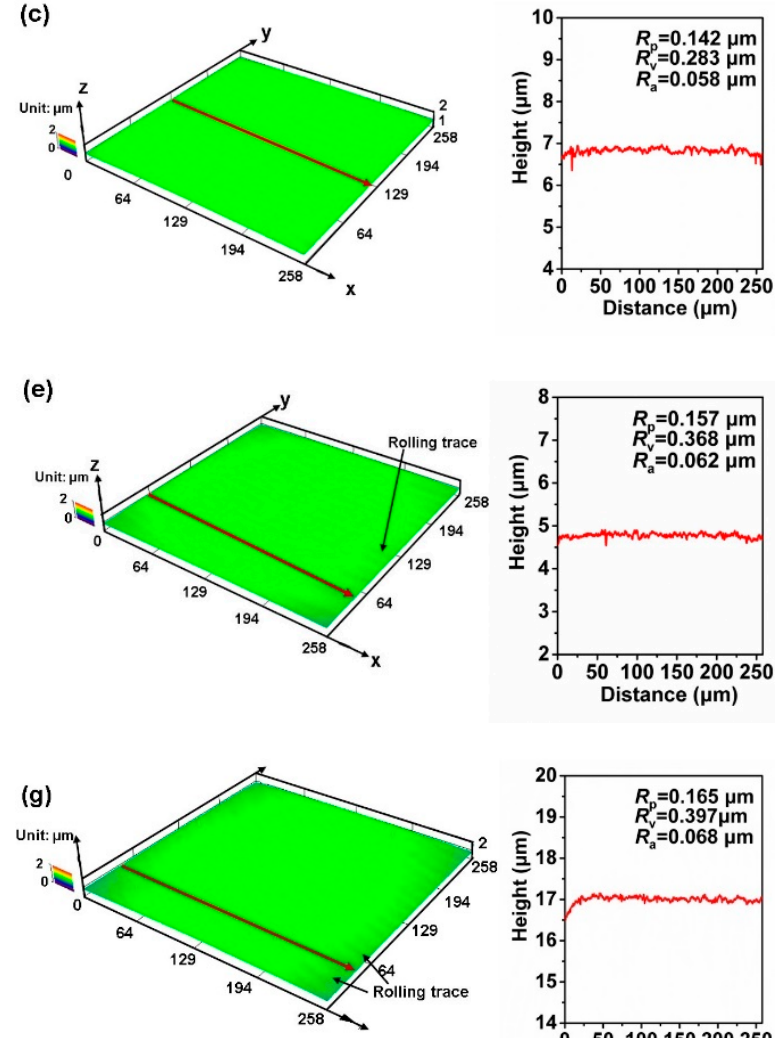

(b)
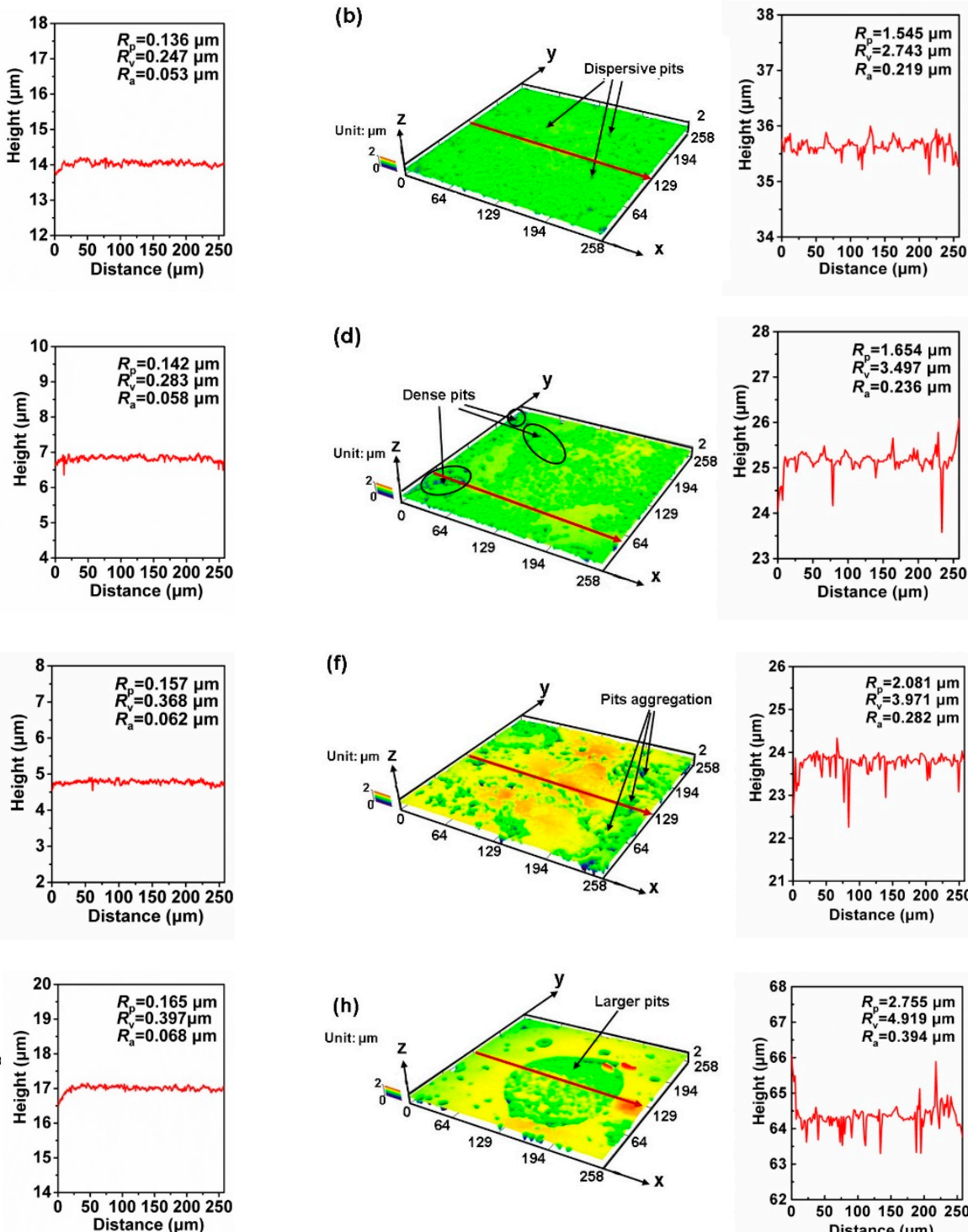

(d)
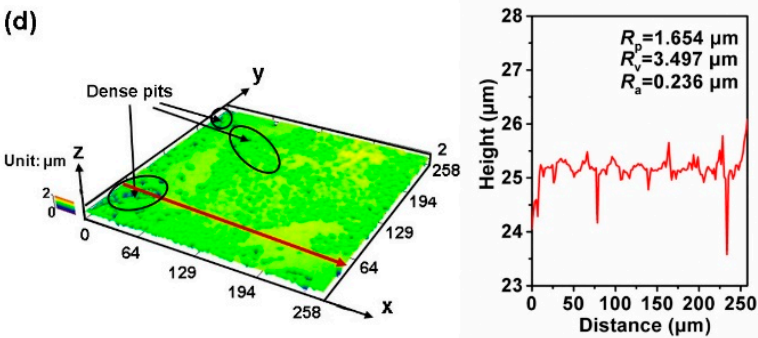

(f)
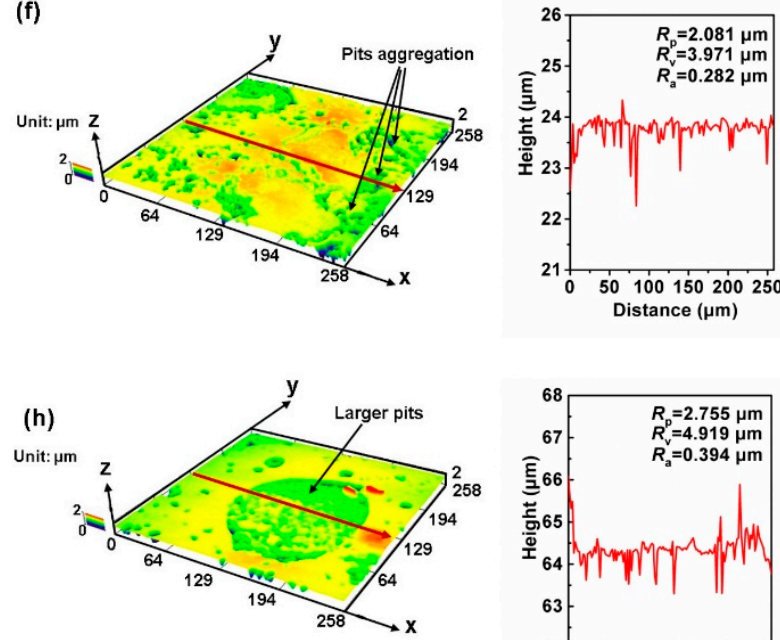

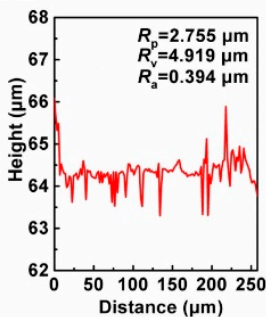

Figure 5. The 3D topographies and height profiles of the $\mathrm{Cu}$ electrodes before and after the electrochemical tests under different rolling reductions: (a,b) $0 \%$, (c,d) $22.7 \%$, (e,f) $58.6 \%$, and (g,h) $77.3 \%$.

Figure 6 shows the FE-SEM images of the Cu electrodes under different cold rolling reductions before and after the electrochemical experiments. After mechanical polishing, a small polish trach existed on the electrode surface, and the surface morphologies showed different degrees of pits after the electrochemical tests. The surface morphology of the raw strip electrode (Figure $6 \mathrm{~b}$ ) was relatively uniform and appeared to have less scattered corrosion pits. Corrosion pits exhibited various degrees of expansion as the rolling proceeded. As shown in Figure 6d, 20.7\% rolling reduction was found to cause some small pits to connect with other pits. When the reduction increased to $58.6 \%$ (Figure $6 \mathrm{f}$ ), the 
density of the pits increased significantly, becoming dense and covering the entire surface. These corrosion pits eventually existed in the form of huge pitting corrosion when the $\mathrm{Cu}$ strip experienced $77.3 \%$ reduction (Figure $6 \mathrm{~h}$ ), and its morphology was seriously damaged under this circumstance.
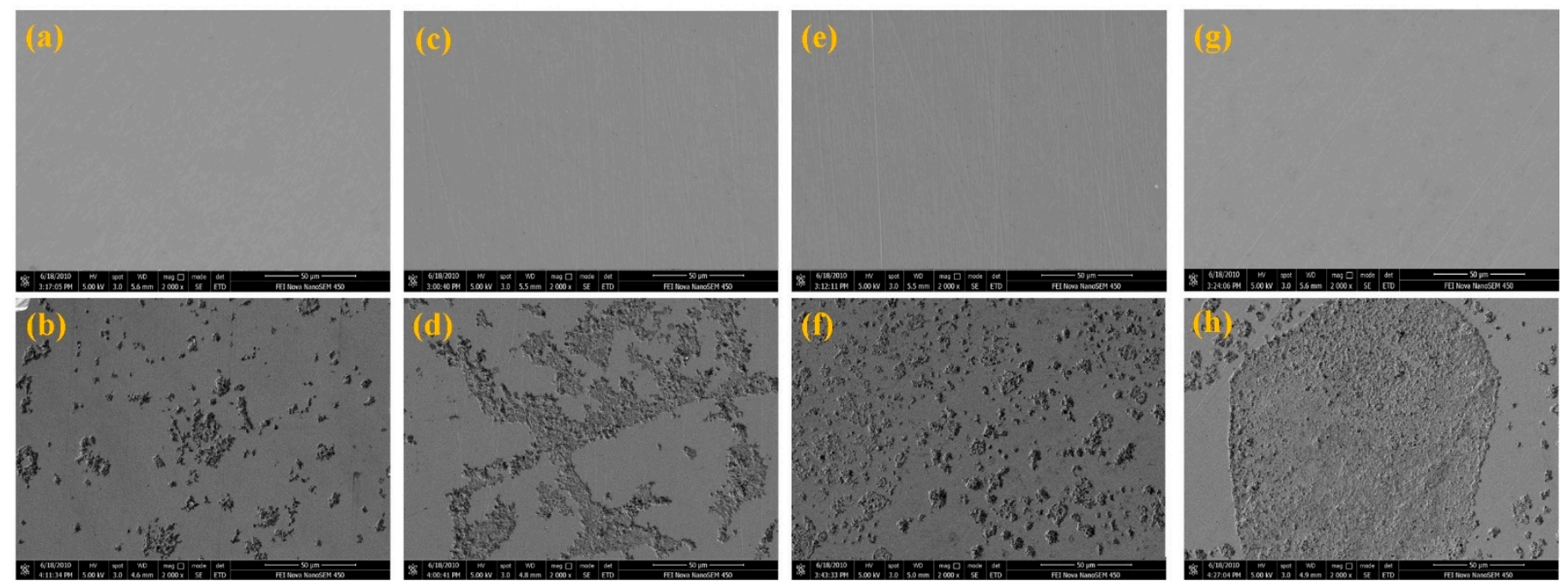

Figure 6. SEM morphologies of $\mathrm{Cu}$ electrodes before and after the electrochemical tests under different rolling reductions: (a,b) $0 \%$, (c,d) $22.7 \%$, (e,f) $58.6 \%$, and $(\mathbf{g}, \mathbf{h}) 77.3 \%$.

The corrosion characteristics of these pits were further investigated using highresolution scanning electron microscopy (HR-SEM). Taking the $58.6 \%$ rolled $\mathrm{Cu}$ strip as an example, as shown in Figure 7a,b, some large sphere-like pits (marked by white arrows) and small metastable pits (marked by red arrows) were observed on the surface. The diameter of the large pits was around $7 \mu \mathrm{m}$, and with metastable pits ranging from 0.7 to $1.3 \mu \mathrm{m}$. Clearly, the whole surface could be divided into three parts, including the uncorroded layer, interface, and corroded layer, as shown in Figure 7c. The morphology of the uncorroded layer seemed clean and flat. The interface was loose and accompanied by the occurrence of some cracks. Pits grew on the corroded surface and formed the granulate corrosion products. The EDS surface scanning mappings are shown in Figure $7 \mathrm{~d}$, and it can be seen that $\mathrm{Cu}$ element was mainly distributed on the uncorroded surface, while the $\mathrm{Cl}, \mathrm{S}$, and $\mathrm{C}$ elements were mostly distributed on the corroded surface. This phenomenon indicates that pitting corrosion is derived from these $\mathrm{Cl}, \mathrm{S}$, and $\mathrm{C}$ contents in the $\mathrm{O} / \mathrm{W}$ emulsions.

The XPS analysis of the corrosion pits on the rolled Cu strip was performed after the morphology observation, and the results are shown in Figure 8. The binding energy of some of the standard compounds of $\mathrm{Cu}, \mathrm{O}, \mathrm{C}, \mathrm{S}, \mathrm{Cl}$, and $\mathrm{P}$ contents are listed in the plots, which were obtained from the NIST XPS database. Firstly, as shown in Figure 8a, the peaks detected at the binding energy of $952.56 \mathrm{eV}, 952.7 \mathrm{eV}$, and $952.5 \mathrm{eV}(\mathrm{Cu} 2 \mathrm{p} 1 / 2)$ represent metallic $\mathrm{Cu}, \mathrm{CuO}$, and $\mathrm{Cu}_{2} \mathrm{O}$, respectively [26-28]. On the other hand, the fitted peak detected at $932.5 \mathrm{eV}(\mathrm{Cu} 2 \mathrm{p} 3 / 2)$ could be constructed by five separation peaks, indicating the presence of some $\mathrm{Cu}$ (I) and $\mathrm{Cu}$ (II) compounds. In the $\mathrm{O} 1 \mathrm{~s}$ spectrum, as Figure $8 \mathrm{~b}$ shows, the peaks at $532.81 \mathrm{eV}$ were indicative of $\mathrm{C}=\mathrm{O} / \mathrm{C}-\mathrm{O}$ organic compounds. The other peak appeared at $532.2 \mathrm{eV}$, combined with $935.0 \mathrm{eV}$ in the $\mathrm{Cu} 2 \mathrm{p} 3 / 2$ spectrum (Figure 8a) and $168.15 \mathrm{eV}$ in the $\mathrm{S} 2 \mathrm{p}$ spectrum (Figure $8 \mathrm{c}$ ), and the existence of $\mathrm{CuSO}_{4}$ could be confirmed [29]. Furthermore, the binding energy of the $C 1$ s spectrum (Figure 8d) showed a strong peak at $284.6 \mathrm{eV}$, representing the existence of $\mathrm{C}-\mathrm{C}$ and $\mathrm{C}-\mathrm{H}$ in the emulsifier oils [11]. In addition to the saturated carbon chain, a weak peak was detected at $287.3 \mathrm{eV}$. This is related to the carbonate groups $\left(\mathrm{CO}_{3}^{2-}\right)$, indicating the existence of $\mathrm{CuCO}_{3}$ compounds [30]. From Figure $8 \mathrm{e}$, it is seen that $\mathrm{P}$ element did not experience any chemical reactions with $\mathrm{Cu}$ and the peak detected at $134.1 \mathrm{eV}$ was therefore indicative of undecomposed phos- 
phate [31]. Another important finding is depicted in the $\mathrm{Cl} 2 \mathrm{p}$ spectrum (Figure $8 \mathrm{f}$ ). The peak was significantly divided into two separation peaks located at $199.1 \mathrm{eV}$ and $198.2 \mathrm{eV}$, representing $\mathrm{CuCl}$ and $\mathrm{CuCl}_{2}^{-}$, respectively [32,33]. These compounds were the main factors that caused severe pitting corrosion on the $\mathrm{Cu}$ surface.
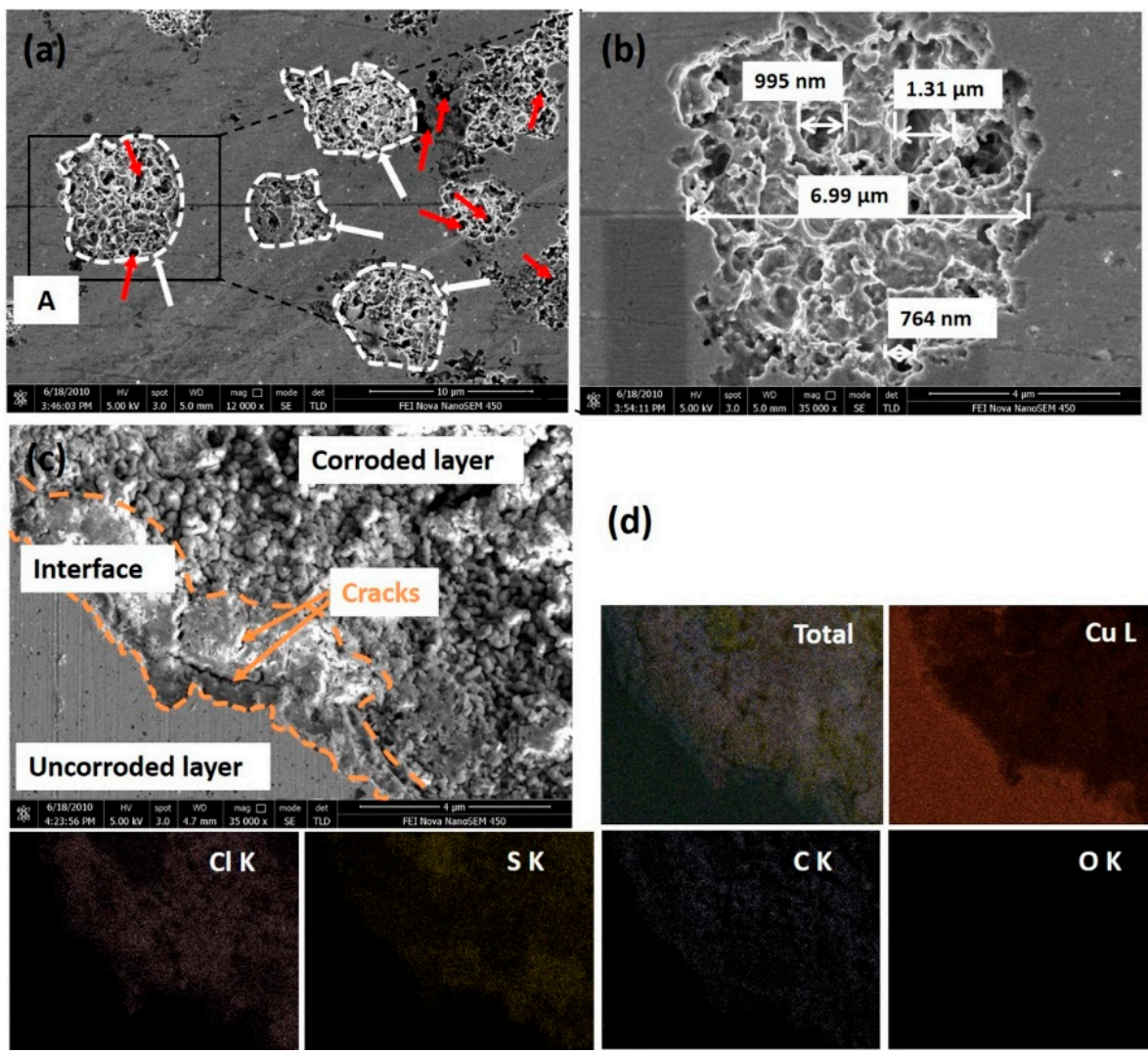

(d)

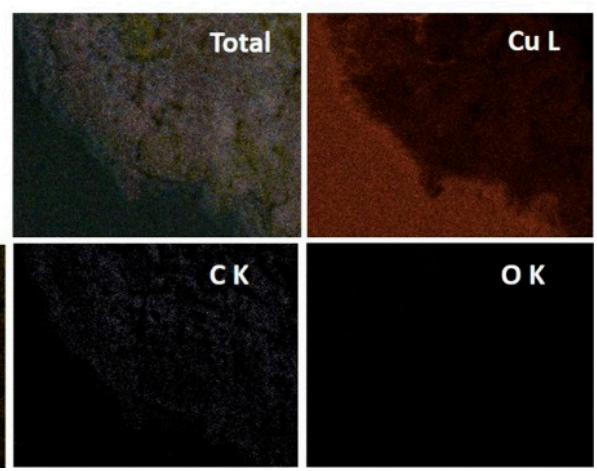

Figure 7. HR-SEM images and EDS analysis of the $58.6 \%$ reduced $\mathrm{Cu}$ surface after the electrochemical experiments: (a) HR-SEM images of the corrosion pits; (b) magnification of site A in Figure 7a; (c) morphology of corroded layer, interface and uncorroded layer; and (d) EDS surface scanning mappings of Figure 7c.

\subsection{Microstructure and Mechanical Properties}

It is widely believed that cold rolling changes the microstructure and properties of metals. The variation of the metal corrosion property is related to its microstructure [14,34,35]. Figure 9 presents the EBSD mapping for the microstructure of $\mathrm{Cu}$ strips under different cold rolling reductions. The statistical data of the grain size and grain boundaries (GBs) variations are shown in Table 7 . It is apparent that the average grains size $\left(D_{\text {adv }}\right)$ of the $\mathrm{Cu}$ strips were refined from $5.21 \mu \mathrm{m}$ to $2.42 \mu \mathrm{m}$, while the total number of GBs increased with the cold rolling operations. As shown in Figure 9a, the grains of the raw $\mathrm{Cu}$ strip were relatively homogenous and a small portion of twin boundaries (TBs) occurred at the surface. With the accumulation of the rolling reduction (shown in Figure 9b-d), the grains became blurry and the GBs were gradually broken. Generally, a $15^{\circ}$ criterion was employed to define high-angle boundaries (HAGBs) vs. low-angle boundaries (LAGBs) [36]. As shown in Table 5, the fraction of HAGBs was found to decrease with the rolling reduction, meanwhile that of LAGBs increased. 
(a)

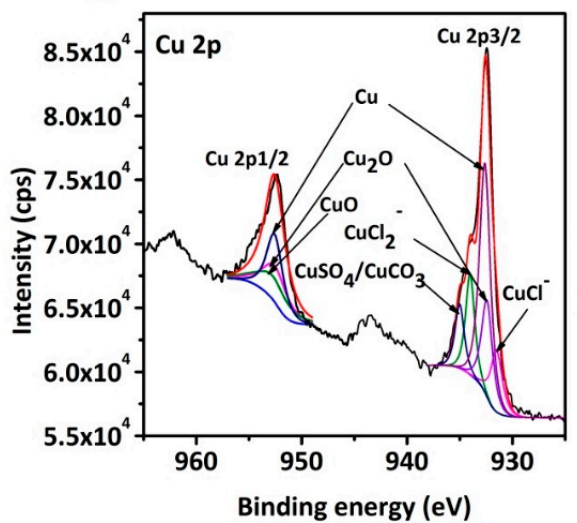

(d)

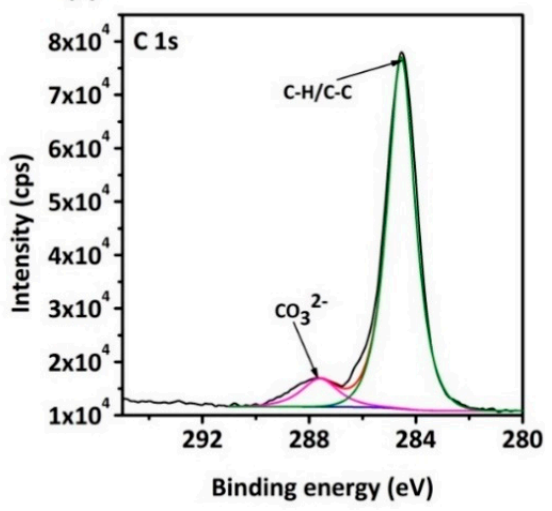

(b)

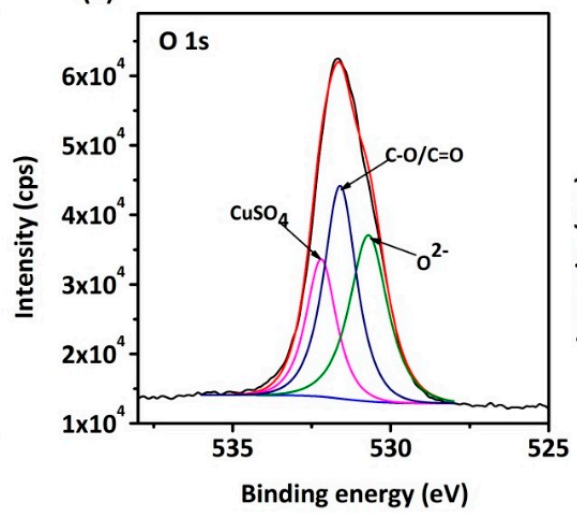

(e)

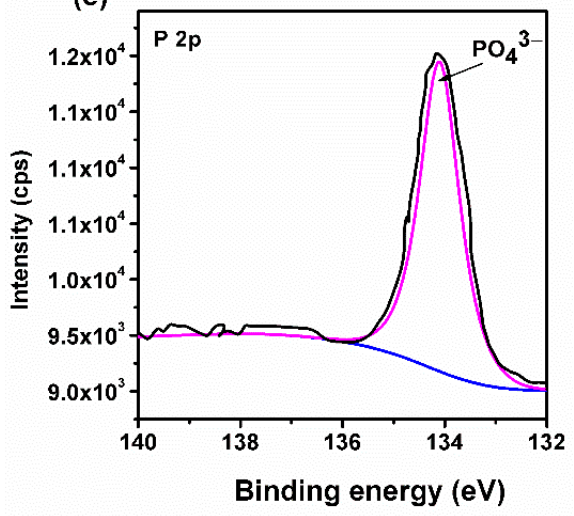

(c)

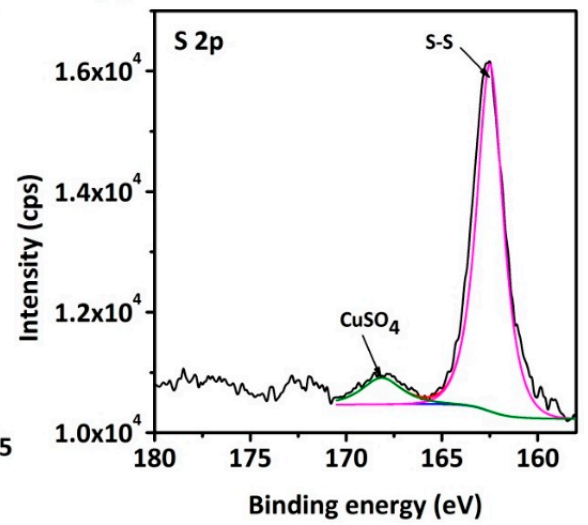

(f)

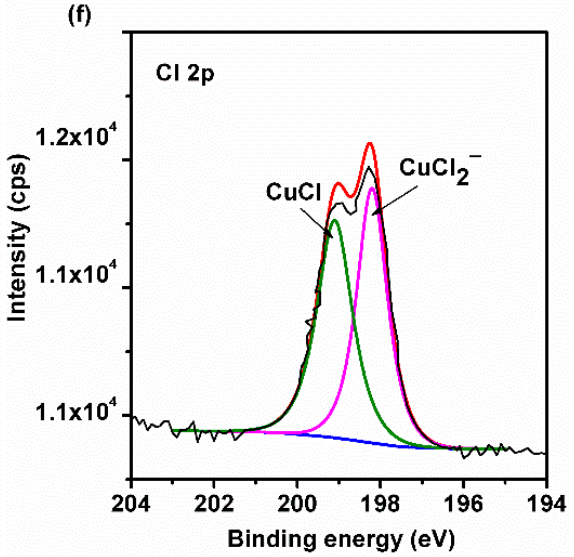

Figure 8. XPS spectra of the corrosion pits of the $\mathrm{Cu}$ strip after the electrochemical experiment: (a) Cu 2p, (b) O 1s, (c) S 2p, (d) C 1s, (e) P 2p, and (f) Cl 1s.
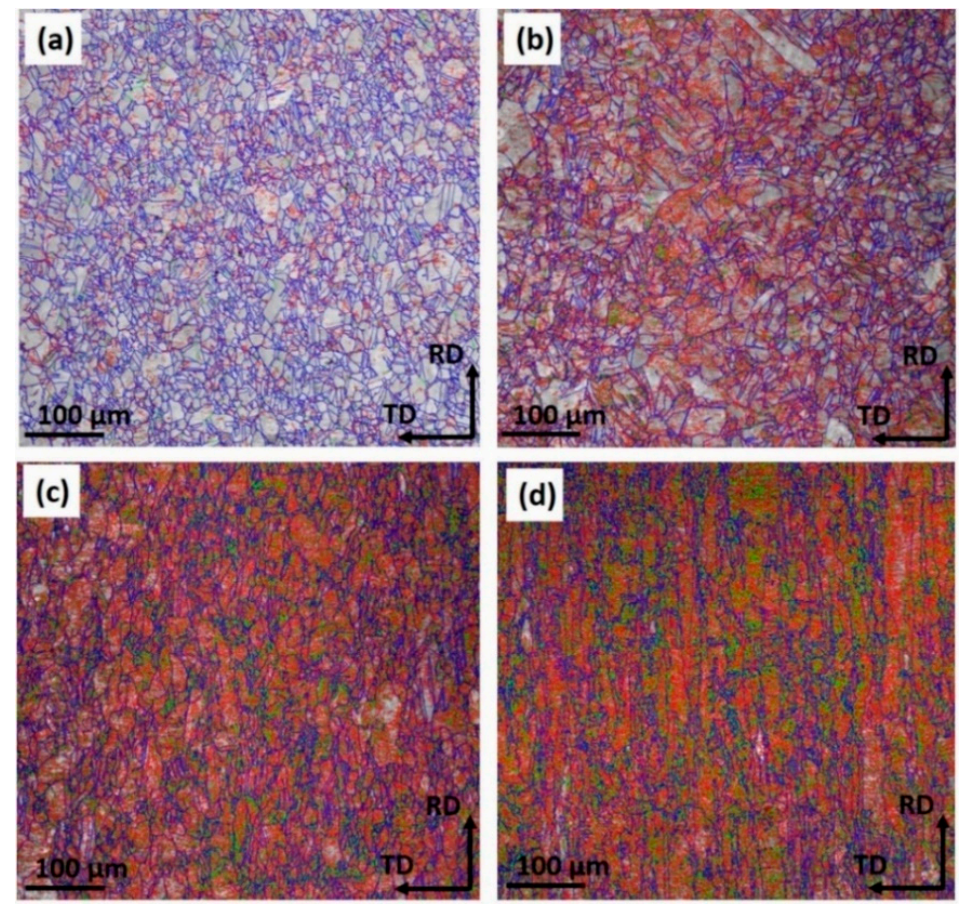

Figure 9. EBSD mapping of microstructures for $\mathrm{Cu}$ strips under different cold rolling reductions after being corroded by $\mathrm{O} / \mathrm{W}$ emulsions. (a) $0 \%$ reduction, (b) $22.7 \%$ reduction, (c) $58.6 \%$ reduction, and (d) $77.3 \%$ reduction (in the EBSD mappings, red, green, and blue lines represent the angle of $2-5^{\circ}$, $5-15^{\circ}$, and $15-180^{\circ}$ boundaries, respectively.). 
Table 7. Statistical data of the grain size and grain boundary variations.

\begin{tabular}{ccccc}
\hline Reduction & $0 \%$ & $20.7 \%$ & $58.6 \%$ & $77.3 \%$ \\
$\boldsymbol{D}_{\text {adv }}(\boldsymbol{\mu m})$ & 5.21 & 5.14 & 3.08 & 2.42 \\
Number of GBs & 285,646 & 463,615 & 971,524 & $13,543,64$ \\
Number of LAGBs & 82,266 & 305,522 & 745,159 & $10,672,39$ \\
Fraction of LAGBs (\%) & 28.8 & 65.9 & 76.7 & 78.8 \\
Number of HAGBs & 203,380 & 158,093 & 226,365 & 287,125 \\
Fraction of HAGBs (\%) & 71.2 & 34.1 & 23.3 & 21.2 \\
\hline
\end{tabular}

Figure 10 shows the variations of the misorientation distribution and inverse polar figure (IPF) of the rolled $\mathrm{Cu}$ strips. The peaks of misorientation distributions were mainly located at $55-65^{\circ}$ on the misorientation axis and $0-10^{\circ}$ on the misorientation axis. The peak of distribution located at $55-65^{\circ}$ on the misorientation axis probably represents the $<111>$ TBs. It was found that the fraction of $55-65^{\circ}$ on the misorientation axis exhibited a reduction tendency (from 39.7 to 5.1\%). Similarly, from the IPF results, the maximum values of TBs also reduced from 5.59 to 3.48. As cold deformation promoted the grain boundaries to be elongated or rotated along the rolling direction [37], the role of deformation compatibility caused an increase of LAGBs.

(a)

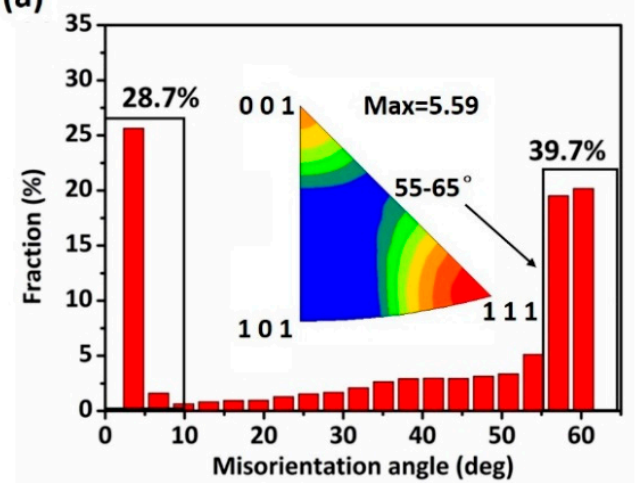

(c)

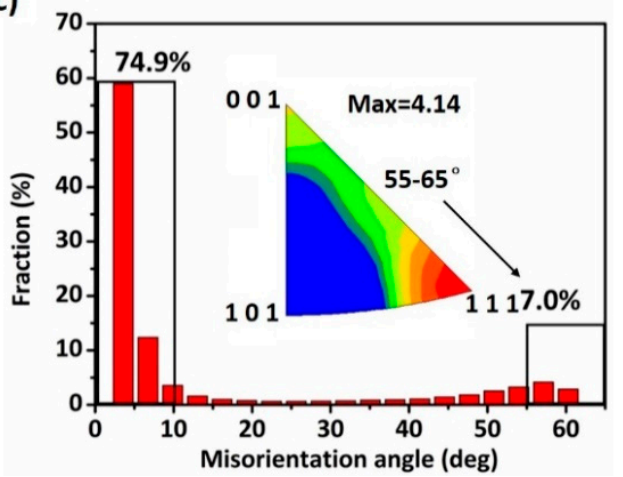

(b)

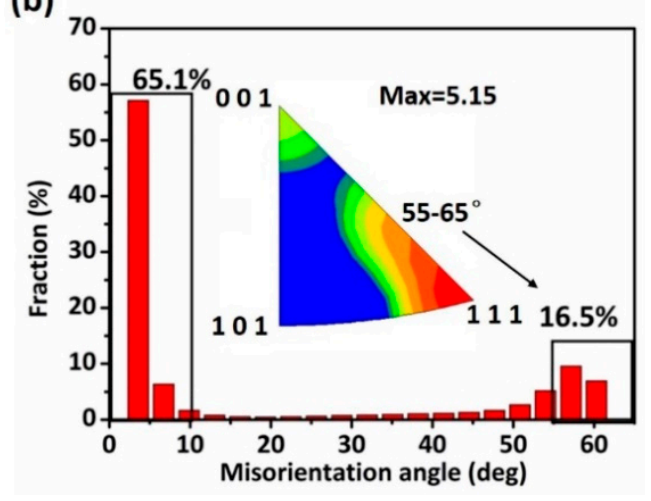

(d)

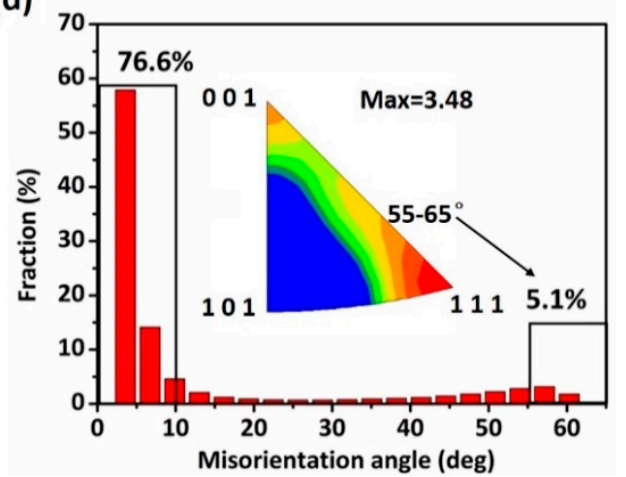

Figure 10. Misorientation distribution and inverse polar figures of $\mathrm{Cu}$ strips under different cold rolling reductions: (a) $0 \%$ reduction, (b) $22.7 \%$ reduction, (c) $58.6 \%$ reduction, and (d) $77.3 \%$ reduction.

From the perspective of the microstructure, the variations of the grain size and grain boundary were derived from the presence of rolling residual stress on metal, which is the key characteristic that deteriorates the corrosion properties of the material $[38,39]$. In the case of the rolled $\mathrm{Cu}$ strips, the variation of the mechanical properties caused by deformation strengthening played a vital role in its subsequent corrosion.

Table 8 presents the mechanical properties of the near-pit regions on the rolled $\mathrm{Cu}$ strip surfaces. The fracture toughness $\left(K_{\mathrm{IC}}\right)$ of the $\mathrm{Cu}$ strips was found to be decreased with the rolling extensions, while the absolute value of the residual stress $\left(\sigma_{\gamma}\right)$ increased. $\sigma_{\gamma}$ of the $77.3 \%$ rolled strip increased to $-593.38 \mathrm{MPa}$, and a negative value represented 
the compressive stress. In the case of a large reduction, more crystal defects and cracks were be generated at the surface microstructure of the $\mathrm{Cu}$ strip. Due to the accumulation of residual stress, it was easy to induce stress corrosion in the material interior, which further increased the corrosive tendency and caused the expansion of the pitting corrosion [40].

Table 8. Mechanical properties of the near-pit regions on $\mathrm{Cu}$ strip surfaces with different reductions.

\begin{tabular}{cccccc}
\hline$\varepsilon$ & $D / \mu \mathbf{m}$ & $H / \mathbf{M P a}$ & $\boldsymbol{C} / \boldsymbol{\mu m}$ & $\boldsymbol{K}_{\mathrm{IC}} / \mathbf{M P a} \cdot \mathbf{m}^{\mathbf{1} / \mathbf{2}}$ & $\sigma_{\boldsymbol{\gamma}} / \mathbf{M P a}$ \\
\hline $0 \%$ & 165.79 & 221.76 & 69.48 & 15.38 & -35.69 \\
$20.7 \%$ & 1297.67 & 251.64 & 106.76 & 11.25 & -238.43 \\
$58.6 \%$ & 356.36 & 286.67 & 139.47 & 8.78 & -296.45 \\
$77.3 \%$ & 386.37 & 357.73 & 156.98 & 3.21 & -598.38 \\
\hline
\end{tabular}

\subsection{FIB and TEM Results}

In order to give an in-depth study on the corrosion mechanism of $\mathrm{Cu}$ strips under different cold rolling reductions, the FIB technique was performed to characterize the cross-sectional microstructure of the corrosion pits. The cross-section microstructure of the corrosion pits on the $20.7 \%$ reduced $\mathrm{Cu}$ sample is shown in Figure 11a. It was found that the size along the depth of the entire pit was around $2.32 \mu \mathrm{m}$. A small portion of metastable pits and microcracks was observed inside the corrosion pit. Nevertheless, as the cold rolling reduction accumulated to $77.3 \%$ (Figure 11b), the depth of pit increased to $3.18 \mu \mathrm{m}$. Meanwhile, the metastable pits and microcracks became more intensive and larger accordingly. These metastable pits and microcracks were distributed along the rolling directions, indicating that pitting corrosion tends to be distributed in regions with more defects and deformations.
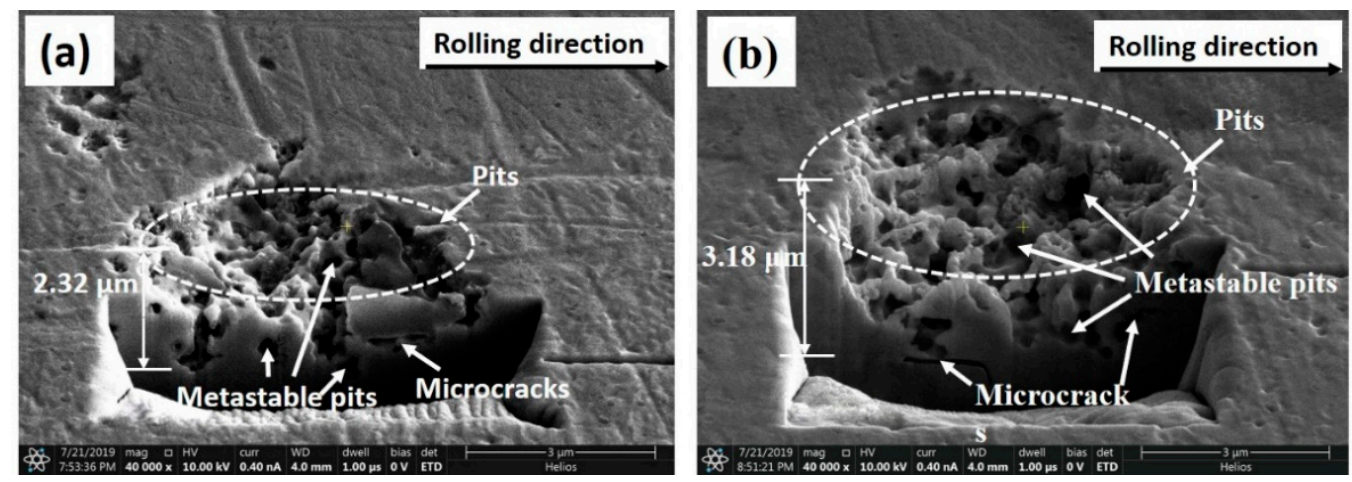

Figure 11. FIB-SEM cross-section microstructure of the corrosion pits of $\mathrm{Cu}$ strips under small and large reductions: (a) $22.7 \%$ reduction and (b) $77.3 \%$ reduction.

A similar phenomenon can be observed from the TEM micrographs. The dislocation configurations on the microstructure of the $20.7 \%$ reduced $\mathrm{Cu}$ strip are shown in Figure 12a,b. It can be seen that only a few dislocation sources appeared in the uncorroded site, whereas a large number of dislocation cells appeared in the near-pits region. As for the $77.3 \%$ reduced strip (shown in Figure 12c), some modulated structures were observed in the uncorroded region, which could be regarded as the sub-structure that appeared at the local region. This phenomenon is related to the broken of grain boundaries caused by large plastic deformation. Additionally, in the near-pits region (Figure 12d), the number of dislocations was found to increase remarkably in comparison with the $20.7 \%$ reduced strip. It can be clearly seen that a long dislocation wall formed on the microstructure by dislocation entanglements. These results are consistent with the previous surface and microstructure observations. 

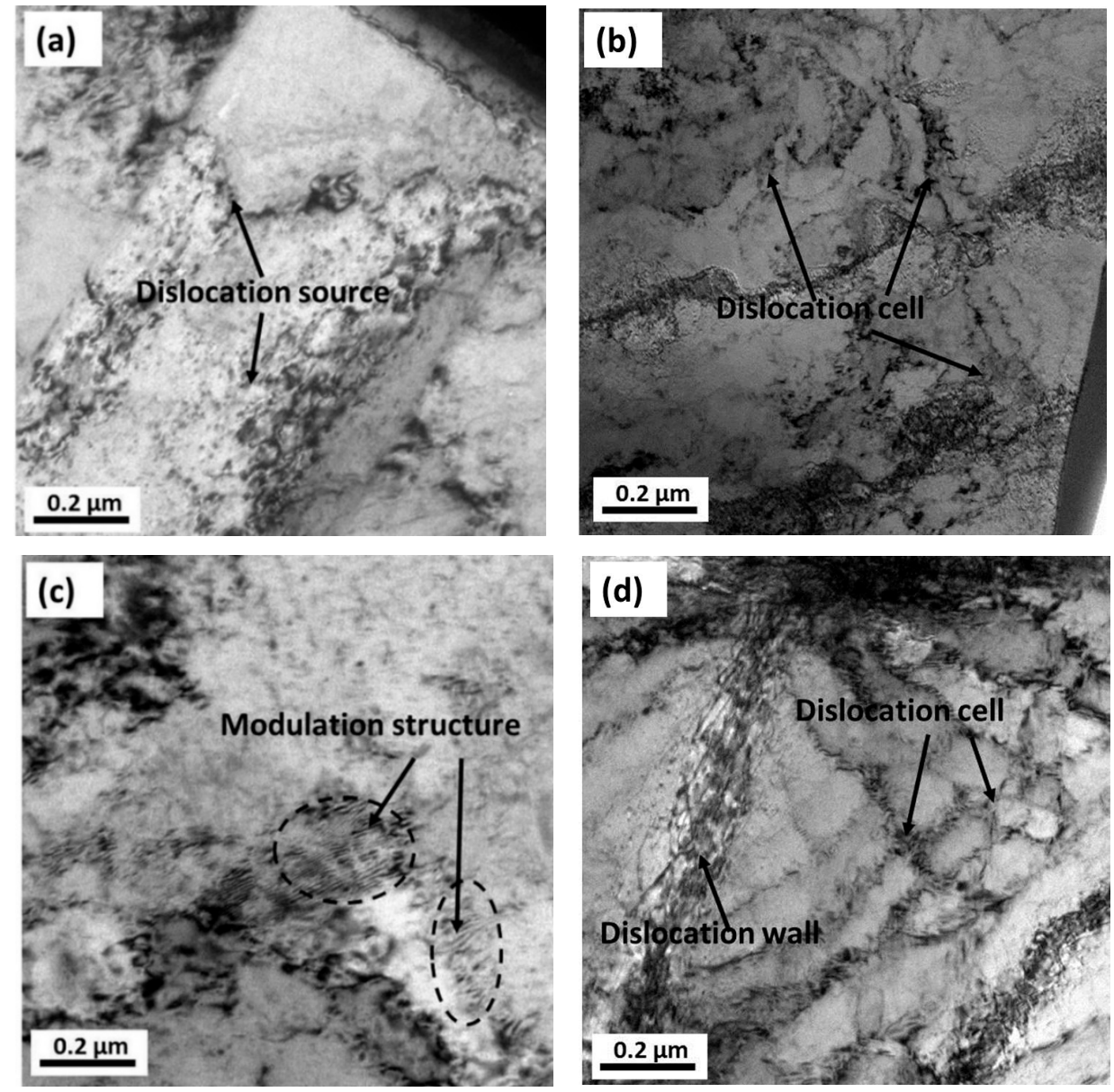

Figure 12. TEM bright field images of different regions of the rolled $\mathrm{Cu}$ strips: (a) uncorroded site of $20.7 \%$ reduced strip, (b) near-pit site of $20.7 \%$ reduced strip, and (c) uncorroded site of the $77.3 \%$ reduced strip, (d) near-pit site of $77.3 \%$ reduced strip.

\subsection{Discussions}

On the basis of the above results, it was found that the corrosivity tendency of $\mathrm{Cu}$ strips under different cold rolling reductions $(\varepsilon)$ in $\mathrm{O} / \mathrm{W}$ emulsions followed the order of $\varepsilon_{0 \%}<\varepsilon_{20.7 \%}<\varepsilon_{50.6 \%}<\varepsilon_{77.3 \%}$., The residual stress on the surface microstructure increased due to the cold rolling deformations, resulting in the refinement of grains, broken of GBs, increase of LAGBs, and decrease of HAGBs. Furthermore, surface defects such as metastable pits, microcracks, and dislocation cells were found to increase with the reduction accumulations. With the role of $\mathrm{O} / \mathrm{W}$ emulsions, $\mathrm{Cl}, \mathrm{C}$, and $\mathrm{S}$ elements were significantly distributed on the corroded surface. Among them, $\mathrm{Cu}$ was likely to react with the $\mathrm{Cl}^{-}$ component in the anodic region [41,42]:

$$
\begin{gathered}
\mathrm{Cu}+\mathrm{Cl}^{-} \rightarrow \mathrm{CuCl}+\mathrm{e}^{-} \\
\mathrm{CuCl}+\mathrm{Cl}^{-} \rightarrow \mathrm{CuCl}_{2}^{-} \\
\mathrm{CuCl}_{2}^{-} \rightarrow \mathrm{Cu}^{2+}+2 \mathrm{Cl}^{-}+\mathrm{e}^{-}
\end{gathered}
$$

Meanwhile, the oxygen in the emulsion solutions as well as other anions such as $\mathrm{SO}_{4}^{2-}$ and $\mathrm{CO}_{3}^{2-}$ also play significant roles in the electrode reaction:

$$
\begin{gathered}
2 \mathrm{Cu}+1 / 2 \mathrm{O}_{2} \rightarrow \mathrm{Cu}_{2} \mathrm{O} \\
2 \mathrm{CuCl}_{2}^{-}+\mathrm{H}_{2} \mathrm{O} \rightarrow \mathrm{Cu}_{2} \mathrm{O}+2 \mathrm{H}^{+}+4 \mathrm{Cl}^{-}
\end{gathered}
$$




$$
\begin{gathered}
\mathrm{Cu}^{2+}+2 \mathrm{RCOO}^{-} \rightarrow \mathrm{CuCO}_{3}+\mathrm{R}-\mathrm{R}+\mathrm{CO} \\
\mathrm{Cu}^{2+}+\mathrm{SO}_{4}{ }^{2-} \rightarrow \mathrm{CuSO}_{4}
\end{gathered}
$$

Furthermore, the corrosion products were proven to be $\mathrm{CuCl}, \mathrm{CuCl}_{2}^{-}, \mathrm{Cu}_{2} \mathrm{O}, \mathrm{CuCO}_{3}$, and $\mathrm{CuSO}_{4}[11,30,43-45]$, appearing in the form of pitting corrosion on the $\mathrm{Cu}$ surface. These corrosion products eventually caused the presence of large cathodic areas surrounded by small anodic corrosion sites [46]. Therefore, under the interactive effect of pitting corrosion and stress corrosion, pits expanded along the rolling direction. Anions aggregated in surface defects such as dislocations, metastable pits, and microcracks, thus the corrosion eventually evolved into pitting corrosion, which is more serious. The mode of the whole corrosion behavior of the $\mathrm{Cu}$ strip rolled with $\mathrm{O} / \mathrm{W}$ emulsions is depicted as Figure 13a, and the mechanism of corrosion expansion is shown in Figure 13b.

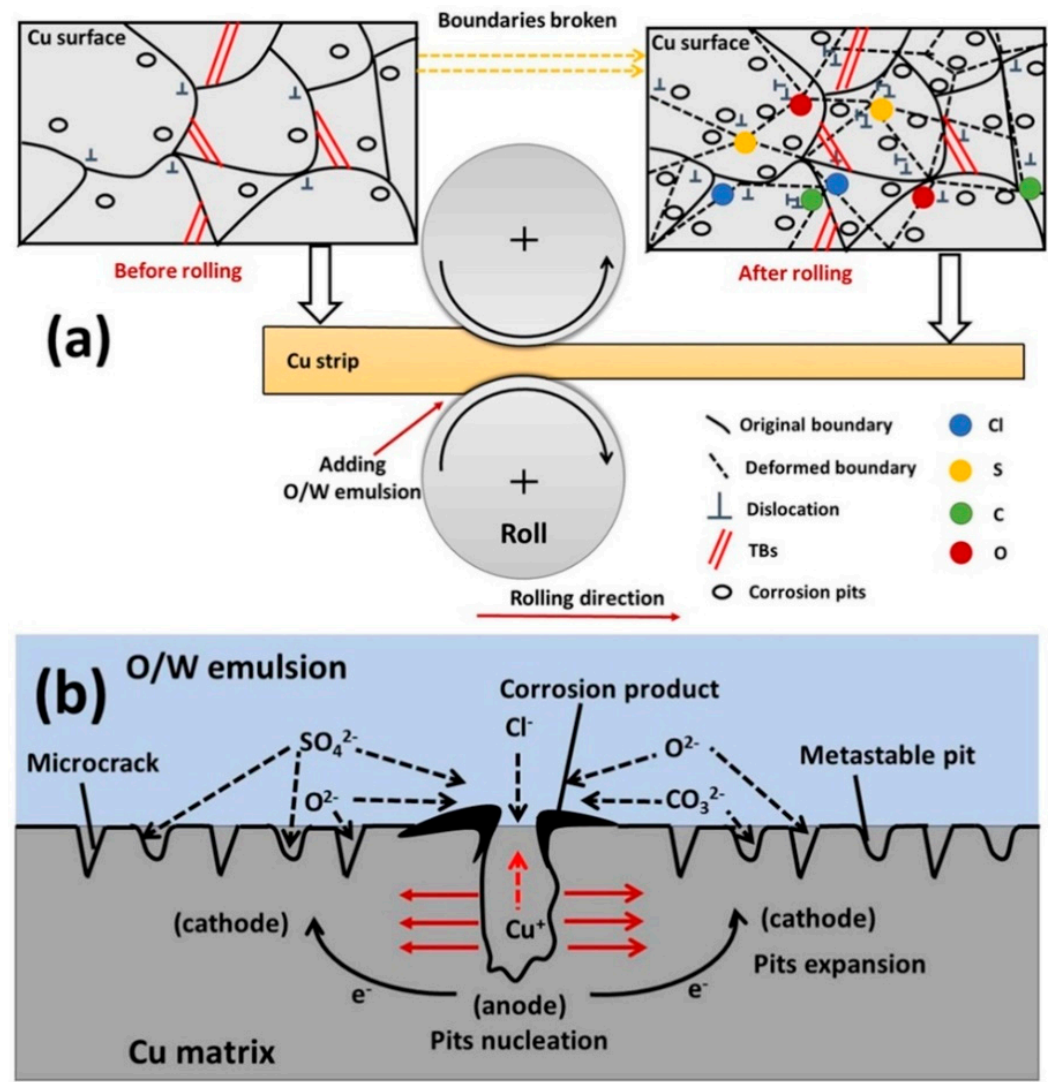

Figure 13. (a) Mode of the whole corrosion behavior of a $\mathrm{Cu}$ strip rolled with $\mathrm{O} / \mathrm{W}$ emulsions; (b) mechanism of pitting corrosion expansion.

\section{Conclusions}

In this paper, the effect of cold rolling reduction on the pitting corrosion behavior and microstructure of $\mathrm{Cu}$ strips in $\mathrm{O} / \mathrm{W}$ emulsions were systematically investigated through a combination of electrochemical experiments, surface and corroded microstructural observations, and mechanical property analysis. The primary conclusions are drawn as follows:

(1) The electrochemical results show the corrosion current densities of $\mathrm{Cu}$ strips in the $\mathrm{O} / \mathrm{W}$ emulsions increased with accumulated reduction, while the corrosion potentials shifted towards being more negative in the anodic region. The pitting potentials and corrosion resistances were both decreased with the processing of cold rolling. These phenomena demonstrated that the corrosive tendency of $\mathrm{Cu}$ strips under different rolling reduction $(\varepsilon)$ followed the order of $\varepsilon_{0} \%<\varepsilon_{20.7 \%}<\varepsilon_{50.6 \%}<\varepsilon_{77.3 \%}$.

(2) Surface observations indicated that there were different degrees of pit expansions that occurred on the rolled $\mathrm{Cu}$ surfaces. These pits became denser and the surface became rougher with the increase of rolling reduction. Some metastable pits existed 
in the larger pits. $\mathrm{Cu}$ reacted easily with chlorine, sulfur, and carbon components from the $\mathrm{O} / \mathrm{W}$ emulsions, Then, the corrosion products, i.e., $\mathrm{CuCl}, \mathrm{CuCl}_{2}^{-}, \mathrm{Cu}_{2} \mathrm{O}$, $\mathrm{CuCO}_{3}$, and $\mathrm{CuSO}_{4}$ were generated, which appeared in the form of pitting corrosion on the $\mathrm{Cu}$ surface.

(3) EBSD mappings demonstrated the average grain size of $\mathrm{Cu}$ strips refined from $5.21 \mu \mathrm{m}$ to $2.42 \mu \mathrm{m}$ with the accumulated reduction. The fraction of low-angle boundaries increased, while that of high-angle boundaries decreased. This was due to the accumulation of residual stress, which induced stress corrosion in the material interior, further increased the corrosive tendency, and contributed to the expansion of the pitting corrosion.

(4) From the TEM and FIB characterizations, it is concluded that corrosion pits expanded along the rolling direction under the interactive effect of pitting corrosion and stress corrosion. Meanwhile, anions aggregated in the surface defects, such as dislocations, metastable pits, and microcracks, which thereby accelerated the pitting corrosion of the surface.

Author Contributions: X.Y., experiments, microanalysis, and original manuscript; J.S., supervision, review and editing, and revised draft. All authors have read and agreed to the published version of the manuscript.

Funding: The authors gratefully acknowledge the financial support of the National Natural Science Foundation of China (nos. 51474025 and 51874036).

Institutional Review Board Statement: Not applicable.

Informed Consent Statement: Not applicable.

Data Availability Statement: The data presented in this work are available on request from the corresponding author.

Conflicts of Interest: The authors declare no conflict of interest.

\section{References}

1. Solmaz, R.; Şahin, E.A.; Döner, A.; Kardaş, G. The investigation of synergistic inhibition effect of rhodanine and iodide ion on the corrosion of copper in sulphuric acid solution. Corros. Sci. 2011, 53, 3231-3240. [CrossRef]

2. Ghelichkhaha, Z.; Sharifi-Aslb, S.; Farhadia, K.; Banisaieda, S.; Ahmadic, S.; Macdonald, D.D. L-cysteine/polydopamine nanoparticle-coatings for copper corrosion protection. Corros. Sci. 2015, 91, 129-139. [CrossRef]

3. Gelman, D.; Starosvetsky, D.; Ein-Eli, Y. Copper corrosion mitigation by binary inhibitor compositions of potassium sorbate and benzotriazole. Corros. Sci. 2014, 718, 610-619. [CrossRef]

4. Sherif, E.M.; Park, S.M. Effects of 2-amino-5-ethylthio-1,3,4-thiadiazole on copper corrosion as a corrosion inhibitor in aerated acidic pickling solutions. Electrochim. Acta 2006, 51, 6556-6562. [CrossRef]

5. Liu, T.; Yin, Y.; Chen, S.; Chang, X.; Cheng, S. Super-hydrophobic surfaces improve corrosion resistance of copper in seawater. Electrochim. Acta 2007, 52, 3709-3713. [CrossRef]

6. Zhang, D.; Gao, L.; Zhou, G. Inhibition of copper corrosion by bis-(1-benzotriazolymethylene)-(2,5-thiadiazoly)-disulfide in chloride media. Appl. Surf. Sci. 2004, 225, 287-293. [CrossRef]

7. Yan, J.; Zeng, X.; Ren, T.; Heide, E. Boundary lubrication of stainless steel and CoCrMo alloy based on phosphorous and boron compounds in oil-in-water emulsion. Appl. Surf. Sci. 2014, 315, 415-424. [CrossRef]

8. Yan, X.; Sun, J.; Xiong, S.; Hou, Y. Insights into the sliding wear behavior of a copper-steel pair with oils containing extremepressure additives. Wear 2017, 386-387, 211-217. [CrossRef]

9. Dong, C.; Sun, J.; Cheng, Z.; Hou, Y.Q. Preparation and tribological properties of a microemulsion for magnesium alloy warm rolling. Ind. Lubr. Tribol. 2019, 71, 74-82. [CrossRef]

10. Xiong, S.; Si, J.; Sun, J.; Wu, H.; Dong, H.; Zhang, C. Experimental and computational studies on heterocyclic organic compounds as corrosion inhibitors for copper immersed in O/W emulsion medium. Anti-Corros. Method Mater. 2020, 2, 214-227. [CrossRef]

11. Yan, X.; Sun, J.; Meng, Y. Experimental insight into the chemical corrosion mechanism of copper with an oil-in-water emulsion solution. RSC Adv. 2018, 8, 9833-9840. [CrossRef]

12. Yan, X.; Sun, J. Effect of water hardness and $\mathrm{pH}$ value on the corrosion behavior of copper in an emulsion. Int. J. Electrochem. Sci. 2017, 12, 11580-11593. [CrossRef]

13. Deng, H.; Yi, J.; Xia, C.; Yi, Y. Improving the mechanical properties of carbon nanotube-reinforced pure copper matrix composites by spark plasma sintering and hot rolling. Mater. Lett. 2018, 210, 177-181. [CrossRef] 
14. Robin, A.; Martinez, G.A.S.; Suzuki, P.A. Effect of cold-working process on corrosion behavior of copper. Mater. Des. 2012, 34, 319-324. [CrossRef]

15. Lapeire, L.; Lombardia, E.M.; De Graeve, I.; Terryn, H.; Verbeken, K. Influence of grain size on the electrochemical behavior of pure copper. J. Mater. Sci. 2017, 52, 1501-1510. [CrossRef]

16. Deng, W.; Lin, P.; Li, Q.; Mo, G. Ultrafine-grained copper produced by machining and its unusual electrochemical corrosion resistance in acidic chloride pickling solutions. Corros. Sci. 2013, 74, 44-49. [CrossRef]

17. Nikfahm, A.; Danaee, I.; Ashrafi, A.; Toroghinejad, M.R. Effect of grain size changes on corrosion behavior of copper produced by accumulative roll bonding process. Mater. Sci. Mater. Res.-Ibero-Am. J. Mater. 2013, 16, 1379-1386. [CrossRef]

18. Xiong, S.; Sun, J.L.; Xu, Y.; Yan, X.D. Effect of Lubricants and Annealing Treatment on the Electrical Conductivity and Microstructure of Rolled Copper Foil. J. Electron. Mater. 2015, 44, 2432-2439. [CrossRef]

19. Brian, R.L.; Edwin, R.F. Measurement of thin-layer surface stresses by indentation fracture. J. Mater. Sci. 1984, 19, 4061-4067.

20. Diard, J.P.; Le Canut, M.L.; Le Gorrec, B.; Montella, C. Copper electrodissolution in $1 \mathrm{M} \mathrm{HCl}$ at low current densities, I. General steady-state study. Electrochim. Acta 1998, 43, 2469-2483. [CrossRef]

21. Qiang, Y.; Zhang, S.; Xu, S.; Yin, L. The effect of 5-nitroindazole as an inhibitor for the corrosion of copper in a $3.0 \% \mathrm{NaCl}$ solution. RSC Adv. 2015, 5, 63866-63873. [CrossRef]

22. Gholami, M.; Hoseinpoor, M.; Moayed, M.H. A statistical study on the effect of annealing temperature on pitting corrosion resistance of 2205 duplex stainless steel. Corros. Sci. 2015, 94, 156-164. [CrossRef]

23. Qiang, Y.; Zhang, S.; Yan, S.; Zou, X.; Chen, S. Three indazole derivatives as corrosion inhibitors of copper in a neutral chloride solutions. Corros. Sci. 2017, 126, 295-304. [CrossRef]

24. Wang, D.; Xiang, B.; Liang, Y.P.; Song, S.; Liu, C. Corrosion control of copper in 3.5wt.\% NaCl Solution by Domperidone: Experimental and Theoretical Study. Corros. Sci. 2014, 85, 77-86. [CrossRef]

25. Qiang, Y.; Zhang, S.; Guo, L.; Zheng, X.; Xiang, B.; Chen, S. Experimental and theoretical studies of four allyl imidazoliumbasedionic liquids as green inhibitors for copper corrosion in sulfuric acid. Corros. Sci. 2017, 119, 68-78. [CrossRef]

26. Mansour, A.N. Characterization of $\mathrm{LiNiO}_{2}$ by XPS. Surf. Sci. Spectra 1994, 202, 279-286. [CrossRef]

27. Jolley, J.G.; Geesey, G.G.; Hankins, M.R.; Wright, R.B.; Wichlacz, P.L. Auger electron and X-ray photoelectron spectroscopic study of the biocorrosion of copper by alginic acid polysaccharide. Appl. Surf. Sci. 1989, 37, 469-480. [CrossRef]

28. Hussain, Z.; Salim, M.A.; Khan, M.A.; Khawaja, E.E. X-ray photoelectron and auger spectroscopy study of copper-sodiumgermanate glasses. J. Non-Cryst. Solids 1989, 110, 44-52. [CrossRef]

29. Nefedov, V.I.; Firsov, M.N.; Shaplygin, I.S. Electronic structures of $\mathrm{MRhO}_{2}, \mathrm{MRh}_{2} \mathrm{O}_{4}, \mathrm{RhMO}_{4}$ and $\mathrm{Rh}_{2} \mathrm{MO}_{6}$ on the basis of X-ray spectroscopy and ESCA data. J. Electron Spectrosc. Relat. Phenom. 1982, 26, 65-78. [CrossRef]

30. Fazal, M.A.; Haseeb, A.S.M.A.; Masjuki, H.H. Corrosion mechanism of copper in palm biodiesel. Corros. Sci. 2013, 67, 50-59. [CrossRef]

31. Dake, L.S.; Baer, D.R.; Friedrich, D.M. Auger parameter measurements of phosphorus compounds for characterization of phosphazenes. J. Vac. Sci. Technol. A 1989, 7, 1634-1638. [CrossRef]

32. Hashemi, T.; Hogarth, C.A. The mechanism of corrosion inhibition of copper in $\mathrm{NaCl}$ solution by benzotriazole studied by electron spectroscopy. Electrochim. Acta 1988, 33, 1123-1127. [CrossRef]

33. Klein, J.C.; Li, C.P.; Hercules, D.M.; Black, J.F. Decomposition of copper compounds in X-ray Photoelectron Spectrometers. Appl. Spectrosc. 1984, 38, 729-734. [CrossRef]

34. Ding, Y.; Lv, Y.; Chen, K.; Zhao, B.; Han, Y.; Wang, L. Effects of microstructure on the stress corrosion cracking behavior of nickel-aluminum bronze alloy in 3.5\% NaCl solution. Mater. Sci. Eng. A 2018, 733, 361-373. [CrossRef]

35. Gertsman, V.Y.; Bruemmer, S.M. Study of grain boundary character along intergranular stress corrosion crack paths in austenitic alloys. Acta Mater. 2001, 49, 1589-1598. [CrossRef]

36. Konkova, T.; Mironov, S.; Korznikov, A. Microstructure instability in cryogenically deformed copper. Scripta Mater. 2010, 63, 921-924. [CrossRef]

37. Guo, N.; Song, B.; Yu, H.; Xin, R.; Wang, B.; Liu, T. Enhancing tensile strength of Cu by introducing gradient microstructures via a simple torsion deformation. Mater. Des. 2016, 90, 545-555. [CrossRef]

38. Kumar, B.R.; Singh, R.; Mahato, B. Effect of texture on corrosion behavior of AISI 304L stainless steel. Mater. Charact. 2005, 54, 141-147. [CrossRef]

39. Ralston, K.D.; Birbilis, N. Effect of grain size on corrosion: A review. Corrosion 2010, 66, 075005-075005-13. [CrossRef]

40. Van Boven, G.; Chen, W.; Rogge, R. The role of residual stress in neutral pH stress corrosion cracking of pipeline steels. Part I: Pitting and cracking occurrence. Acta Mater. 2007, 55, 29-42. [CrossRef]

41. Hong, S.; Chen, W.; Luo, H.Q.; Li, B.N. Inhibition effect of 4-amino-antipyrine on the Corrosion of copper in 3 wt.\% $\mathrm{NaCl}$ solution. Corros. Sci. 2012, 57, 270-278. [CrossRef]

42. Yu, Y.; Yang, D.; Zhang, D.; Wang, Y.; Gao, L. Anti-corrosion film formed on HAl77-2 copper alloy surface by aliphatic polyamine in 3 wt.\% NaCl solution. Appl. Surf. Sci. 2017, 392, 768-776. [CrossRef]

43. Chen, W.; Hong, S.; Li, H.B.; Luo, H.Q.; Li, M.; Li, B.N. Protection of copper corrosion in $0.5 \mathrm{M}$ Nacl solution by modification of 5-mercapto-3-phenyl-1,3,4-thiadiazole-2-thione potassium self-assembled monolayer. Corros. Sci. 2012, 61, 53-62. [CrossRef]

44. Zhang, X.; Pehkonen, S.O.; Kocherginsky, N.; Ellis, G.A. Copper corrosion in mildly alkaline water with the disinfectant monochloramine. Corros. Sci. 2002, 44, 2507-2528. [CrossRef] 
45. Zelinsky, A.G.; Pirogov, B.Y. Numerical simulation of corrosion process with two-step charge transfer mechanism in the $\mathrm{Cu} / \mathrm{CuSO}_{4}+\mathrm{H}_{2} \mathrm{SO}_{4}$ system. Corros. Sci. 2006, 48, 2867-2881. [CrossRef]

46. Nazarov, A.; Thierry, D. Rate-determining reactions of atmospheric corrosion. Electrochim. Acta 2004, 49, 2717-2724. [CrossRef] 